American University Washington College of Law

Digital Commons @ American University Washington College of

Law

Articles in Law Reviews \& Other Academic Journals

Scholarship \& Research

2007

\title{
A 'Social Dimension' in European Private Law? The Call for Setting a Progressive Agenda
}

Fernanda Nicola

Ugo Mattei

Follow this and additional works at: https://digitalcommons.wcl.american.edu/facsch_lawrev

Part of the International Law Commons, and the Law and Society Commons 


\title{
Global Jurist
}

\author{
Frontiers
}

Volume 7, Issue 1

2007

Article 2

\section{A 'Social Dimension' in European Private Law? The Call for Setting a Progressive Agenda}

\author{
Ugo Mattei* $\quad$ Fernanda G. Nicola $^{\dagger}$
}

*University of Turin (Italy) and UC Hastings College of Law (USA), ugo.mattei@unito.it

${ }^{\dagger}$ Washington College of the Law, American University, fnicola@wcl.american.edu

\section{Recommended Citation}

Ugo Mattei and Fernanda G. Nicola (2007) “A 'Social Dimension' in European Private Law? The Call for Setting a Progressive Agenda," Global Jurist: Vol. 7: Iss. 1 (Frontiers), Article 2. 


\title{
A 'Social Dimension' in European Private Law? The Call for Setting a Progressive Agenda* $^{*}$
}

\author{
Ugo Mattei and Fernanda G. Nicola
}

\begin{abstract}
I. The Europeanization of Private Law: Legal Sources, Ideology and Process: 1. Legal Sources in European Private Law. 2. Technocracy at work: What is the Common Frame of Reference? 3. The Ideological Divide: Neo-liberalism versus Social Justice in European Contract law. 4. The Social Justice Manifesto and the Legitimacy of the Process. 5. The Scholarly Industry and its Dark Sides.

II. Social contract law and Social Europe, part of the problem or part of the solution?: 1. The "Social" Critique of Formalism in Contract Law and its historical inadequacy. 2. The Critique of the Social and its erasure in the Manifesto. 3. Social Europe: A Solution or a Competitive Hegemonic Project? 4. Social Europe versus Socialist Europe.

III. Setting a Progressive Agenda in European Private Law: 1. Re-politicizing the Process. 2. Toward a Transformative Agenda for European Private Law. 3. Restructuring the Field: Constitutions and Codes. 4. Restructuring the Field: Whose Access to Justice? 5. Diversity and Diswibution: Why should we care?
\end{abstract}

KEYWORDS: European private law industry, social justice, progressive agenda, distribution, access to justice

${ }^{*}$ A version of this article is forthcoming on New England Law Review (December 2006). Ugo Mattei - Alfred and Hanna Fromm Professor of International and Comparative Law, U.C. Hastings; Professore Ordinario di Diritto Civile, Universita' di Torino. Part of this paper has been written at the Centro Linceo Interdisciplinare Segre, Accademia Nazionale dei Lincei, Rome, where I am currently serving as a Research Associate. A lecture based on this paper has been delivered at the New England School of Law, March 2, 2006 and a talk at the Harvard Law School at the Symposium on Legal Diffusion of the Harvard International Law Journal ( March, 4, 2006). Fernanda Nicola - Associate Professor, Washington College of the Law, American University, Adjunct Professor at New England School of Law. We wish to thank Duncan Kennedy, Mauro Bussani, Daniela Caruso, Michele Graziadei, Maria Rosaria Marella, Arnulf Becker Lorca and Anna di Robilant for ongoing conversations on this topic and their helpful comments on this work. 
Mattei and Nicola: A 'Social Dimension' in European Private Law?

"A philosophy of praxis cannot but present itself at the outset in a polemical and critical guise, as superseding the existing mode of thinking and existing concrete thought (the existing cultural world). First of all, therefore, it must be a criticism of 'common sense', basing itself initially, however, on common sense in order to demonstrate that 'everyone' is a philosopher and that it is not a question of introducing from scratch a scientific form of thought into everyone's individual life, but of renovating and making 'critical' an already existing activity." I

\section{Introduction}

It is difficult to introduce a reader not privy to the current debate on European private law, what it is understood by "social dimension" within it. Indeed the idea is quite minimal and it has been spelled out in a recent "Manifesto on Social Justice in European Private Law", in which a group of scholars have dedicated a few academic meetings to express the feeling that the current "technocratic" clothing of legal Europe is highly questionable; that European private law cannot be constructed as a merely technical, neutral, exercise of institution building, but rather its "political dimension" should be clearly recognized; that, to the contrary, Brussels handles the European private law process as a matter strictly functional to the needs of the construction of an open market; and that what suffers in this process is "social justice."

While the foes of the project are clearly spelled out in the Manifesto as the "technocrats and bureaucrats" in Brussels, a lot of self-restraint is exercised when it comes to a self critique of the role of legal academia in the process of Europeanization of Private law. In contrast, we portray as deeply problematic the many issues related to a line of scholarship now developing as a well founded industry by the institutions in Brussels. ${ }^{3}$

\footnotetext{
${ }^{1}$ Antonio Gramsci, Selections from the Prison Notebooks 330 (International Publishers, trans. Quintin Hoare and Geoffrey Nowell Smith, 1971). See the influence of Gramsci on PARTHA Chatterjee, The Nation and its Fragments: Colonial and Postcolonial Histories (1993).

${ }^{2}$ See Social Justice in European Contract Law: A Manifesto, Study Group on Social Justice in European private Law, rapporteur Hugh Collins, 10 EUR. L.J. 6, 653-674 (2004) [hereinafter the Social Justice Manifesto].

${ }^{3}$ While some resource-controlling scholars are more ready to yield to a pattern of influence and prestige connected to the self-appointed role of "private legislators", others have allied with the project of resisting the European Commission agenda while coalescing around the Social Justice Manifesto.
} 
This paper aims to show what are the political, rather than the technical stakes in the current debate over the harmonization of private law in Europe. Part One analyzes the main actors, the legal sources, the ideological divide and the process animating the current debate on European Private Law. It sheds light on the incremental transformation of European private law in a scholarly industry. Part Two sheds light on the main obstacles and inconsistencies that jurists encounter in envisioning a Social private law. We argue that the notion of the "Social" in private law scholarship as well as the idea of "Social Europe" is rarely a useful notion to articulate a progressive agenda for European private law. Finally, in Part Three we offer some modest proposal of methodological and strategic nature on the possibilities and the limitations of setting a progressive agenda for European Private Law. We argue that a progressive agenda for European private law can be conceived today as a significant platform only by breaking with the current hegemonies and ideologies as well as by unveiling the transformation of European private law into a scholarly industry.

In light of Antonio Gramsci's notion of a philosophy of praxis, we hope that this paper will spark further thoughts and self-criticism on current mainstream, progressive and neoliberal project tackling the harmonization of private law in the European Union.

\section{The Europeanization of Private Law: Legal Sources, Ideology and Process}

\section{Legal Sources in European Private Law}

It will be useful for our reader not familiar in the intricacies of E.U. law to offer some context in which the current issues are unfolding. Unlike the United States, the EU did not create a system of federal courts, thus what is largely understood as European private law results from a complex interplay of harmonizing directives and national private law regimes. The process of private law harmonization encompasses a large number of legal sources and institutional actors both at the European and at the national level. ${ }^{4}$

European private law comprises a variety of legal rules, which derive from legislative, judicial and scholarly sources operating at different levels of government. ${ }^{5}$ The legislative source of European private law comprises both the

\footnotetext{
${ }^{4}$ Sources of law also known in comparative law as legal formants primarily refer to a legislative, judicial and scholarly source. See Rodolfo Sacco, Legal Formants. A Dynamic Approach to Comparative Law, 39 AM. J. COMP. L. 1 (1991); ROdOLFO SACCO, InTRODUZIONE AL DIRITTO COMPARATO, 1980; Rodolfo Sacco, Souvenirs d'un vieux comparatiste, 10 ZEITSCHRIFT FüR EUROPÄISCHES PRIVATRECHT [Z. Eu. P.] 727 (2002).

${ }^{5}$ See P.G. Monateri \& Rodolfo Sacco, Legal Formants, in The New Palgrave Dictionary of ECONOMICS AND THE LAW, 531 (Peter Newman ed., 1998).
} 
body of EU legislation, namely directives that created a patchwork harmonization of private law rules, and national legal rules enshrined in continental Civil Codes, "which in some cases are naturally converging." Finally, European private law encompasses also those legal provisions, which transpose European directives that Member States introduced into their pre-existent civil codes. European lawyers have therefore plunged in this complicated scenario in which European legal traditions encounter different legal sources as well as different levels of governments. ${ }^{7}$ Our essay predominantly focuses on the legislative source, namely a number of directives that the European Commission has proposed to harmonize the field of European private law. ${ }^{8}$ The Community institutions include the European Commission, the Council of Ministers, and the European Parliament. The Commission acts both as a legislative and as an executive branch and is composed by twenty-five commissioners who are appointed for five years with the power to initiate legislative processes. ${ }^{9}$ The Council of Ministers is composed by representatives at ministerial level of the twenty-five Member States, who can commit their government to Community policies. ${ }^{10}$ The European Parliament (EP) is composed of 732 members, who are directly elected by European citizens for five-year terms. Together, the Council and the EP perform as a two-house legislature adopting Community acts, which can be either regulations or directives. While regulations have general application, are binding in their entirety and are directly applicable in all Member States, directives need to be transposed into Member States' legal orders to become fully binding. ${ }^{11}$ Even though Member States are obliged to attain the goal set up by the directive or "the result to be achieved," they maintain discretion over implementing measures. ${ }^{12}$

Under Articles 94 and $95 \mathrm{EC}$, which indicate that the goal of harmonization is the establishment and functioning of the internal market, the Community enjoys a relatively broad power to issue directives to harmonize

${ }^{6}$ See Aurelia Colombi-Ciacchi, Late Payment Directive of the EC and its implementation, E.R.P.L. (2005).

${ }^{7}$ See Mathias Reimann, The Progress and Failure of Comparative Law in the Second Half of the Twentieth Century, 50 AM. J. COMP. L. 4, 671-700 (2002).

${ }^{8}$ In particular we will use as an example a well-know directive in European contract law, Council Directive 93/13/EEC of 5 of April 1993 O.J. (L095) 29-34 [hereinafter Unfair Terms directive].

${ }^{9}$ See EC Treaty art. 211 (defining the power of the Commission); see also Paul Craig and Gráinne de Búrca, EU Law : Text, Cases, and Materials, 59 (3d ed. 2003)..

${ }^{10}$ See EC Treaty art. 203; see also Paul Craig and Gráinne de Búrca, supra, at 65.

${ }^{11}$ See EC Treaty art. 249.

12 See EC Treaty art. 249 EC. Directives are distinct from classic federal legislation in that Member States can choose with some flexibility, which type of national instrument to implement in order to achieve the prescribed goal. See Paul Craig and Gráinne de Búrca, supra note 10 at 114-15. 
specific private law rules. ${ }^{13}$ The main difference between these provisions is that under Article $94 \mathrm{EC}$ the Council decides by unanimity after consulting the EP, whereas under Article 95 EC the Council decides by majority voting through the co-decision procedure, whereby the EP has a co-equal role. ${ }^{14}$ First introduced by the Maastricht Treaty, today the co-decision procedure or "Community-method" has become the basic Community legislative process. ${ }^{15}$ Under Article $251 \mathrm{EC}$ the co-decision proceeds as follows: the Commission drafts a text, then the Council and the EP can amend and approve the text through the adoption of a common position or the intervention of a conciliation committee. Following the approval of a directive, Member States must transpose it into their national legal systems.

In the mid-1980s the Commission began the harmonization of private law in the realm of consumer contracts for door-to-door sales and product liability rules. ${ }^{16}$ By the end of the 1980 s, numerous consumer contracts directives created a body of European private law tackling consumer policy, which was only expressly included under the competence of the Community by the Maastricht Treaty (1992). ${ }^{17}$ Even though these directives regulated consumer issues, their main goal was the establishment and functioning of the internal market, based on Article $95 \mathrm{EC}$, rather than the creation of a body of European consumer policy under Article $153 \mathrm{EC}^{18}$

\footnotetext{
${ }^{13}$ The term "harmonization" or approximation of the laws was introduced in the original Treaty of Rome (1958) under article 100 (now 94EC) with the goal of eliminating the distortions of competition created by the laws of the Member States. The Single European Act (1987) adopted article 100A (now $95 \mathrm{EC}$ ) which required majority voting rather than unanimity to achieve the approximation of national measures for the establishment and functioning of the common market. In contrast, Moreover, under Article $95 \mathrm{EC}$ the Council decides via majority voting through a codecision procedure, art $251 \mathrm{EC}$ in which Council and EP share equal powers, see http://europa.eu.int/eur-lex/lex/en/treaties/index.htm; Walter van Gerven, Harmonization of Private Law: Do we need it?, 41 C.M.L.R. 505 (2004).

${ }^{14}$ The co-decision procedure is laid down in EC Treaty art. 251 (ex-189b).

${ }^{15}$ See PAUl CRAIG \& GRÁINNE DE BÚRCA, supra note 10 at $144-147$; on the Community method see Joanne Scott and David M. Trubek, Mind the Gap: Law and New Approaches to Governance in the European Union, 8 EUR. L.J. 1, 1-18 (2002).

${ }^{16}$ See Council Directive 85/577/EEC, 1985 O.J. (L 372) 31-33. to protect the consumer in respect of contracts negotiated away from business premises (hereinafter Doorstep Selling directive) and the Product Liability directive.

${ }^{17}$ See EC Treaty art. 153; STEPHEN WEATHERILL; supra note 9 (describing how EC consumer policy constructed its identity in the shadow of fundamental constitutional omissions from the original treaty); see also G. Howells, Soft law and Consumer law in LAW MAKING IN THE EUROPEAN UNION (P. Craig and C. Harlow. Eds., 1998).

${ }^{18}$ From 1985 to 1999 the Commission agenda triggered off seven directives on European contract law. See the GREEN PAPER ON CONSUMER PROTECTION (2001). The most recent European legislation in contract law is the Directive on Consumer Sales and Associated Guarantees (1999/44), described by the EC in the Green Paper as a "recent attempt by the Commission to harmonize the disparate existing laws of the Member States concerning implied warranties in consumer sales" at 7 .
} 
The legal scholarship source of European private law comprises publications, casebooks or doctrinal commentaries addressing European contract and tort law. ${ }^{19}$ These materials enable scholars to expose the views of " $l a$ doctrine" to influence both national and European educational legal systems. In order to obtain greater convergence of European legal education to achieve a European common law, academics advocate for a greater role of scholarship in channelling the harmonization process. ${ }^{20}$ The focus of this essay is primarily on this source and what we will define as the scholarship industry promoted by European lawyers.

Finally, the judicial source in European private law includes the domestic courts jurisprudence, which interprets European directives and the growing body of ECJ jurisprudence. The case law of the ECJ raises tension. This is well known in the United States in the domain of the general federal common law, ${ }^{21}$ and it concerns the role of the ECJ in the interpretation of private law rules, traditionally interpreted by domestic courts. ${ }^{22}$

The ECJ can only interpret directives via two procedural grounds. The first concerns a suit brought before the ECJ by the Commission under Article 226 EC. $^{23}$ The Commission polices Member States for their incorrect or late implementation of directives and has the discretion to sue those governments that are reluctant to follow its recommendations on the "correct" transposition of directives. $^{24}$ This procedure raises numerous problems on what should be the correct transposition of directives by those Member States with profoundly diverse legal systems and national legal traditions. ${ }^{25}$

The second procedural ground allows individuals to bring actions before their national courts raising preliminary questions on the interpretation of EC law. By means of the procedure of Article 234 EC, national judges have the discretion to refer such questions to the ECJ for preliminary rulings. ${ }^{26}$ This instrument has

\footnotetext{
${ }^{19}$ See Christophe Jamin and Phillippe Jestaz, La Doctrine (2004)

${ }^{20}$ See Walter van Gerven, Codifying European Private Law (2001); Bridging (Private) Laws Closer to Each other at the European Level (2005) papers available at http://www.law.kuleuven.ac.be/ccle/pdf/2005-01-18_WvG_.Impact_courts_on_private_law.pdf.

${ }^{21}$ See Erie Railroad v. Tompkins, 304 U.S. 64 (1938) when the U.S. Supreme Court overturned the Swift v. Tyson [1842] by rejecting the existence of a "Federal General Common Law."

${ }^{22}$ See Peter Rott, What is the Role of the ECJ in EC Private Law? A Comment on the ECJ judgments in Océano Grupo, Freiburger Kommunalbauten, Leitner and Veedfald, 1 HANSE L. REV. 6 (2005)

${ }^{23}$ See EC Treaty art. 226.

${ }^{24}$ See Case C-52/00, Comm'n v. France, 2002 E.C.R. I-3827.

${ }^{25}$ See Case C-478/99, Comm'n v. Sweden, 2000 E.C.R. I-04147.

${ }^{26}$ See EC Treaty art. 234 "The Court of Justice shall have jurisdiction to give preliminary rulings concerning: the interpretation of this Treaty; the validity and interpretation of acts of the institutions of the Community and of the ECB; the interpretation of the statutes of bodies established by an act of the Council, where those statutes so provide. Where such a question is
} 
been fundamental to effectively enforce the new rights and remedies granted by EC law directly to individuals and to groups. ${ }^{27}$ Domestic courts have largely contributed to the expansion and application of EC law, even though their behaviour varies significantly in each Member State. Jurists pointed out that within the same legal system, legal elites, who were initially reluctant to refer preliminary questions to the ECJ, later began to deploy preliminary rulings as a means for their judicial empowerment. ${ }^{28}$

Scholars wrote extensively on the uniqueness of this judicial exchange between domestic and European courts, depicting it as a constitutional and participatory dialogue between national and supranational judges. Some jurists stressed how the constitutionalization of EC law has progressively empowered national courts as the "agents of the Community order" vis a vis Member States. ${ }^{29}$ In contrast, others highlighted that such processes vary greatly depending on the attitude of national judges in sheepishly adopting or resisting EC law and its interpretation by the ECJ. ${ }^{30}$

In this vein, by shifting their attention from European integration towards the behaviour of domestic courts and national interest groups, commentators are increasingly focusing on the preliminary reference mechanism as a unique standpoint to understand the judicial dialogue and cooperation in the EU. ${ }^{31}$ Finally, Micklitz has openly addressed the problem of political legitimacy in conjunction with patterns of judicial cooperation in different legal fields. He has highlighted that any inquiry of judicial cooperation in the EU needs to take into account the "preparedness of national courts to use preliminary rulings" as well as "the way in which courts react to ECJ judgments." 32

raised before any court or tribunal of a Member State, that court or tribunal may, if it considers that a decision on the question is necessary to enable it to give judgment, request the Court of Justice to give a ruling thereon. Where any such question is raised in a case pending before a court or tribunal of a Member State against whose decisions there is no judicial remedy under national law, that court or tribunal shall bring the matter before the Court of Justice."

${ }^{27}$ For the EC doctrines of direct effect and state liability see Paul Craig and Gráinne de Búrca, supra note 12.

${ }^{28}$ See Paul Craig, Report on the United Kingdom, at 220-1, in The European CourT AND NATIONAL COURTS: DOCTRINE AND JURISPRUDENCE : LEGAL CHANGE IN ITS SOCIAL CONTEXT (Anne-Marie Slaughter, Alec Stone Sweet, and J.H.H. Weiler eds., 1998).

29 Id.; Alec Stone Sweet, Constitutional Dialogue in the European Community, at 308.

${ }^{30}$ See L. Niglia, The Non-Europeanization of Private Law, ERPL 9, 575 (2001); LISA CONANT, JUSTICE CONTAINED: LAW AND POLITICS IN THE EUROPEAN UNION (2002).

${ }^{31}$ See Labour law in the Courts: National Judges and the European Court of Justice (Silvana Sciarra ed., 2001).

${ }^{32}$ See Hans-W. Micklitz, The Politics of Co-operation in the EU (2005) at 27. 


\section{Technocracy at work: What is the Common Frame of Reference?}

Today, anybody pursuing the task of reading the numerous articles on European private law will encounter the notion of a "Common Frame of Reference", which was created by the European Commission in its attempt to further harmonization while at the same time using a tool which would be perceived by the Member States as a less top-down form of regulation.

The Commission as a hybrid is the EC executive branch but it also retains the power of initiative over Community legislation. In setting its EC legislative agenda, the Commission's committees are continuously consulting the Council, the EP and other supranational bodies to determine the course of future legislative activities. ${ }^{33}$ However, in response to the increasing democratic concerns raised by policy-makers and academics on the Community method, in 2001 the Commission launched an extensively advertised survey of the stakeholders who are likely to be affected by EC regulations. The Commission aimed at improving the quality and the effectiveness of Community re-regulation, while at the same time promoting soft law and new forms of governance to complement the Community method. ${ }^{34}$ In the realm of European contract law the Commission consulted stakeholders and academics on whether to continue with a sectoral intervention, namely via sectoral directives and soft law instruments, or rather adopt a more comprehensive and "hard" European Civil Code. ${ }^{35}$

In February 2003, the European Commission published an Action Plan aimed at achieving greater coherence in European contract law. ${ }^{36}$ The Action Plan continues the ongoing debate with stakeholders and academics launched in 2001 to foster dialogue on the practical as well as technical problems arising from the divergence of national contract law regimes. ${ }^{37}$ By targeting the obstacles, which prevent the 'smooth functioning' of the internal market, the Action Plan aspired to improve the quality of Community regulation through legislative transparency and stakeholders' participation.

In the Action Plan the Commission is careful to take further action in the field of contract law but uncertain on the tools such as hard and soft, sectoral or

\footnotetext{
${ }^{33}$ See Christian Joerges, 'Good Governance' through Comitology?, in EU COMMITTEES: SociaL REGUlation, LAW AND POLITICS (Christian Joerges and Ellen Vos eds., 1999).

${ }^{34}$ See Joanne Scott \& Grainne De Burca G. EDS., Constitutionalism and Governance in EUROPE AND THE UNITED STATES (2006).

${ }^{35}$ See Communication on European Contract Law, COM (2001) 398.

${ }^{36}$ See Communication from the Commission to the European Parliament and the Council - A More Coherent European Contract Law - An Action Plan, COM (2003) 68 final O.J. 2003, C $63 / 01$.

${ }^{37}$ See Communication from the Commission to the Council and the European Parliament on European Contract Law, COM (2001) 398 final, OJ 2001, C 55/01 (hereafter Green Paper); Dirk Staudemayer, The Commission Action Plan on European Contract Law, 2 E.R.P.L. 113(2003) 113-127.
} 
comprehensive measures to achieve an efficient and coherent regulation of contract law. In departing from a European codification, the Action Plan chooses to ameliorate the existent contract acquis communautaire, ${ }^{38}$ by improving its coherence through both hard measures and soft ones, ${ }^{39}$ in particular a non-binding Common Frame of Reference (CFR). ${ }^{40}$ By this point it was already abundantly clear that the harmonization of contract law was the minimalist approach that the Commission could reach more easily and with less opposition than undertaking fields such as property or family law. ${ }^{41}$

Similar to the United States Restatement of Contracts, the CFR aims to increase the coherence of the contract law acquis and to achieve the uniform application of directives. But the language of the Commission carefully avoids the term "code" while adopting the softer notion of CFR. This still obscure tool should provide common principles, terminology and rules for contract law to address gaps, conflicts and ambiguities emerging from the application of European contract law. ${ }^{42}$

\footnotetext{
${ }^{38}$ The acquis communautaire is the result of the body of directives mostly harmonizing consumer contracts and product liability and their common interpretation by the ECJ which constitutes the core of European private law. See R. Schulze, The Acquis Communautaire and the Development of European Contract Law at 15 in R. SchUlze, M. Ebers AND H.C. GRigoleit, InFORMation REQUIREMENTS AND FORMATION OF CONTRACT IN THE ACQUIS COMMUNAUTAIRE (explaining the development of a European contract acquis).

${ }^{39}$ In the field of European private law the Commission has used legislation adopted through the Community method or "hard law" to harmonize European private law. These hard measures (directives, regulations) are enforced by national and European courts and they are mandatory as well as binding tools of regulation. However, in response to the increasing democratic concerns the Community method; in 2001 the Commission launched an extensive inquiry to improve the quality and the effectiveness of Community re-regulation and at the same time promoting soft law and new forms of governance to complement the Community method. Soft law measures are not fully binding, they are voluntary and they can, according to some scholars, achieve better goals by departing from a command and control strategy. See David Trubek and Louise Trubek, Hard and Soft Law in the Construction of Social Europe, 11 ELJ Vol. 3, 343-364 (2005) and GRAINNE DE BurCa AND JoAnNe SCOTt, LAW AND NEW GOVERnANCE IN THE EU AND THE US (2006) at 2-4.

${ }^{40}$ See Communication from the Commission to the European Parliament and the Council - A More Coherent European Contract Law - An Action Plan, COM (2003) 68 final OJ 2003, C 63/01 at 77 addressing consolidation, codification and the existing instruments as possible means to achieve greater coherence and at FN 56 "The codification means the adoption of a new legal instrument which brings together in a single text, but without changing the substance of a previous instrument and it successive amendments, with the new instrument replacing the old one and repealing it".

${ }^{41}$ See on European property law Daniela Caruso, Private Law and Public Stakes in European Integration: The Case of Property, 10 EuR. L.J., 6, 751-765 (2004); and on European family law, Marella Maria Rosaria, The Non-Subversive Function of European Private Law: The Case of Harmonization of Family Law, 12 EuR. L.J., 78-105 (2006).

${ }^{42}$ See Action Plan, Executive Summary at 1, paragraphs 4.1 and 4.1.1 "[...] the Commission will seek to increase, where necessary and possible, coherence between instruments, which are part of
} 
According to the Commission, the non-uniform implementation of directives by Member States leads to inconsistencies and fragmentation of contract regimes, creating different legal rules for the same commercial situation. ${ }^{43}$ The Commission maintains that a non-uniform application of contract rules entails high transaction costs burdening both industries and 'active' consumers in search of precious information. ${ }^{44}$ High transaction costs emerge not only in the phase of formation of cross-border contracts, but also through judicial control over the fairness of contractual terms. ${ }^{45}$ In order to achieve greater coherence in the application of European contract law and consequently reduce transaction costs, the Commission's strictly functionalist approach is to improve the quality of the existing acquis communautaire. In short, the Action Plan reinforces the view that the existence of different contract law regimes creates a barrier to trade for cross-border transactions within the internal market, thus coherence means more efficient outcomes which can be reached through better uniformity in implementation and maximal harmonization. ${ }^{46}$

In response to the Action Plan, the European Parliament, traditionally proactive in matters of private law codification having endorsed this idea since the late 1980s, also recognized the need of further harmonization in order to facilitate cross-border transactions within the internal market. ${ }^{47}$ Even though the EP offered its political guidance to drive further Europeanization of contract law, it warned the Commission not to overstep the boundaries of Community competences. ${ }^{48}$ Article 5 EC, stating the principle of attributed competences of the Community, is the major concern of supranational institutions. In response, the Commission increasingly argued that via greater coherence in the acquis, through maximal

the EC contract law acquis, both in their drafting and in their implementation and application, Proposals will, where appropriate, take into account a common frame of reference, which the Commission intends to elaborate via research and with the help of all interested parties. This common frame of reference should provide for best solutions in terms of common terminology and rules (...)."

${ }^{43}$ See Action Plan at $\S 16-24$ and $\S 57$. On this point see $\mathrm{R}$. Sacco, L'Interprete et la regle de droit europeenne in LES MULTIPLES LANGUES DU DROIT (Rodolfo Sacco ed., 2001).

${ }^{44}$ See Action Plan. at $\S 25-51$.

${ }^{45}$ Id. at $\S 34-36$. - for example more information is necessary for different national mandatory rules limiting or excluding contractual liability.

${ }^{46}$ Id at $\S 57$ "An improved acquis should enhance the uniform application of Community law as well as facilitate the smooth functioning of cross-border transactions, and thereby the completion of the internal market."

${ }^{47}$ See EP final report on the Communication from the Commission to the European Parliament and the Council - A more coherent European contract law - An action plan COM (2003) 68-A50256/2003 9 July 2003). Here the EP argues that new harmonizing directives on contract law should be base EC Treaty art. 95 and, in the aftermath of the Tobacco advertising judgement, there should have as a primary goal the achievement and functioning of the internal market.

${ }^{48}$ See D. Staudemayer, supra note 37 at 116-117. 
harmonization and less differentiation, European contract law would serve the goal of eliminating obstacles to integration, rather than creating new ones.

In drafting the Action Plan the Commission technocrats emphasized that the CFR would eliminate market inefficiencies arising from the diverse implementation of European directives, ensuring greater coherence in their interpretation by courts. According to the Commission, the CFR should provide jurists with a solution to the costly problem of the non-uniform interpretation of European contract law due to vague terms and rules. ${ }^{49}$ In 2004 the Commission was confident that the CFR would improve the coherence of the existing and future acquis. ${ }^{50}$

According to the Action Plan, incoherencies in European contract law are triggered by vague legal concepts introduced by the directives. ${ }^{51}$ In particular, two types of problems arise when the directives contain vague terminology. First, directives adopt "broadly defined legal concepts," therefore leaving too much discretion in their implementation to national legislators or judges. ${ }^{52}$ Second, directives introduce legal concepts that are "alien to the existing national legislation," thus providing puzzlement and leeway for new statutory interpretations by courts. ${ }^{53}$ Thus, when judges face vague terms, they can either interpret them by referring to the broad principles of the acquis communautaire, or they can refer to the particular goals of the directive in question. While the latter interpretation is problematic, because it leads to high "fragmentation of national legislation," according to the Commission the former interpretation will promote greater coherence in European contract law. ${ }^{54}$ As an example the Commission openly referred to the Leitner judgement as a problematic case, because the ECJ followed the substance but not the formal reasoning deployed by

\footnotetext{
${ }^{49}$ See Action Plan at $\S 18$.

${ }^{50}$ See Communication from the Commission to the European Parliament and the Council European Contract Law and the revision of the acquis: the way forward, at 3, COM (2004) 651 (hereinafter The way forward) "[...] the Commission will use the CFR as a toolbox, where appropriate, when presenting proposals to improve the quality and coherence of the existing acquis and future legal instruments in the area of contract law. At the same time, it will serve the purpose of simplifying the acquis. The CFR will provide clear definitions of legal terms, fundamental principles and coherent model rules of contract law, drawing on the EC acquis and on nest solutions found in Member States legal orders."

${ }^{51} I d$. at 2-3 summarizes the four problems addressed by the action plane 1) the use of abstract terms, 2) application of directives 3) differences between national implementing laws 4) inconsistencies in $\mathrm{EC}$ contract law legislation.

${ }^{52}$ See Counsel Directive 90/314/EEC, Package Travel Directive, O.J. (L 158) 59-64, which was the option taken by Advocate general Tizzano in Leitner but the court did not follow. In that case the court preferred to interpret the notion of damage in light of the mere textualist reading of the Package Travel directive

${ }^{53} \mathrm{Id}$. at $\S 19-21$ addressing the ECJ judgments Travel Vac $\S 17$ and Leitner $\S 21$.

${ }^{54}$ See Action Plan, at 21.
} 
the A.G Tizzano in interpreting the notion of damage enshrined in Article 4 of the directive. The A.G. suggested that the notion of damage should be interpreted in light of the acquis communautaire by referring to other European directives and precedents, whereas the ECJ decided to interpret the notion of damage in connection with the limited purpose of the package holiday directive. ${ }^{55}$ In doing so the Court was not constrained from the acquis communautaire, but it interpreted the notion of damage in light of the particular circumstances of the case. The concern raised by the Commission was that the wide interpretive discretion of the ECJ might be in conflict with the goal of the Community decision maker in regulating the single market, thus undermining the legitimacy of EU law.

Recently the Commission has openly selected two legal instruments to achieve greater coherence in European contract law. In October 2004 the Commission committed to a maximal level of harmonization as a means to avoid fragmentation and incoherencies triggered by minimum harmonization rule making in the implementation of directives. Moreover, the CFR aims to provide both European and national judges with uniform principles for interpreting European contract law, as a remedy to the diverse interpretation by domestic courts. ${ }^{56}$ The institutionalization of the common frame of reference is developing day by day and it can be monitored on the Commission website where the names of the new appointees from the Member States are now made public. ${ }^{57}$

The CFR project has divided scholars into two opposite camps supporting and opposing the Commission agenda. On the Commission side, Christian Von Bar maintained that the CFR is an important tool for establishing coherence of European contract law. ${ }^{58}$ Likewise, the Acquis Group claimed that its ability to provide a common terminology as well as common principles to interpret the body of contract rules would be key to fostering coherency in European Contract

\footnotetext{
${ }^{55}$ Case C-168/00, Leitner Simone v. TUI Deutschland GmbH \& Co.KG, 2002 E.C.R. I-2631, 40 C.M.L.R. 4, 937-952 (2002).

${ }^{56}$ See The way forward, supra note 50, at 11 clarifying " The structure envisage for the CFR is that it would first set out common fundamental principles of contract law including guidance on when exceptions to such fundamental principles could be required. Secondly, those fundamental principles would be supported by definitions of key concepts. Thirdly, these principles and definitions would be completed by model rules, forming the bulk of the CRF".

57 See the European Commission website on the European Frame of Reference at http://ec.europa.eu/consumers/cons_int/safe_shop/fair_bus_pract/cont_law/common_frame_ref_en .htm.

${ }^{58}$ See Christian Von Bar and Stephen Swann, A Response to the Action Plan, ERPL 3: 21537(2003) and Von Bar, From Principles to Codification: Prospects for European Private Law, 9 COLUMBia JoURNAL OF EUROPEAN LAW (2002), 379.
} 
law. ${ }^{59}$ In going beyond a mere functional approach, for which the CFR is simply an instrument to achieve better legislation for the internal market, the Acquis group suggested that this tool could be used also by accession countries as a guideline for implementing European law or by practitioners in interpreting directives and then transposing national provisions. ${ }^{60}$

In contrast, jurists committed to the understanding of the practice of contract law and its social implications harshly criticized the CFR. ${ }^{61}$ They claimed that the CFR is a formalist, technocratic and exegetic enterprise launched by the Commission in order to limit the social function of contract law spurring from different national legal traditions. By dismissing the social practices embedded in domestic legal regimes, the CFR could end up reinforcing divergences instead of creating greater uniformity in European contract law. In their view, the CFR promotes a uniform application of European contract law opening the risk of even further technocratic integration. ${ }^{62}$

3. The Ideological Divide: Neo-liberalism versus Social Justice in European Contract law

The scholarly debate on the CFR reflects the current division in European private law scholarship, a division that we can roughly summarize as follows. Currently one of the most important cleavages lies between neoliberal jurists championing for contractual freedom against social justice advocates arguing for welfarist rules within European contract law. This paragraph underlines not only these political divisions but it also shows how legal forms within this debate play an ambiguous role. Social justice advocates are sometime committed to soft law tools and other times champion hard law approaches. ${ }^{63}$ Similarly neoliberal lawyers at time advocate for uniform standards and more often for soft legal tools. An example of this ideological divide pervades the way jurists have been analysing the contradictions in the text of the European Unfair Terms Directive adopted by the European Council in 1993. ${ }^{64}$

Neoliberal jurists have claimed that European contract law was a "constitutive element" of the internal market, one that enhanced its functioning mechanisms by designating the rules of the game. The harmonization of contract law contributed to strengthening the single market by ensuring a level playing

\footnotetext{
${ }^{59}$ See Acquis Group at http://www.acquis-group.org/index.html; G. Ajani and H. Schulte-Nölke, The Action Plan on a more coherent European contract Law: response on behalf of the Acquis Group (2003).

${ }^{60}$ See Ajani and Schulte- Nölke, supra at 2.

${ }^{61}$ See Social Justice Manifesto, supra note 4.

${ }^{62}$ Id; Hugh Collins, Editorial: The Future of European Private Law: An Introduction, 10 EUR. L.

J. 645, 649 (2004).

${ }^{63}$ See supra, note 39 .

${ }^{64}$ See Unfair Terms directive, supra note 10.
} 
field that enhanced individual freedoms. In supporting the harmonizing agenda of the Principles of Contract Law, ${ }^{65}$ these jurists emphasized that the harmonization of contract law could provide greater information to private actors and enhance their private autonomy. ${ }^{66}$ In supporting the idea of a European economic constitution, they argued in favour of a European codification, which guaranteed to each person the disposition of her individual entitlements. Jürgen Basedow maintained that the notion of freedom of contract remained the core idea for a European codification since every individual has the right to affirm his will to enter into a binding contract. In his view, European codification strengthened economic freedoms and counterbalanced the growing importance of consumer regulation that undermined those common values enshrined in the notion of contractual freedom. ${ }^{67}$ For these lawyers the scope of market harmonization was to remedy the market failure created by the cleavage between commercial and non-commercial contractual regimes, which restricted market competition and created informational asymmetry. ${ }^{68}$ These lawyers have tied claims for European codification $^{69}$ to a notion of contract law as a tool for enhancing party autonomy across Member States. ${ }^{70}$

These neoliberal lawyers have devoted great attention to and supported legislative measures proposed by the Commission. However, they have highlighted that Community action should be cautious not to undermine its democratic legitimacy, which is guaranteed by European procedures and mostly by national democratic processes. ${ }^{71}$ For instance, the Community cannot take away individual rights from European citizens that the Treaty has conferred upon

${ }^{65}$ See Principles of European Contract Law. Parts I and II (Ole Lando and Hugh Beale eds., 2000), for a comment see MARTIJN W. HESSELINK, THE NEW EuROPEAN PRIVATE LAW: Essays ON THE FUTURE OF PRIVATE LAW IN EUROPE at 112-13 (2002).

66 See PARTY AUTONOMY AND THE ROLE OF INFORMATION IN THE INTERNAL MARKET (Grundmann, Kerber and Weatherill eds., 2001).

${ }^{67}$ See Jürgen Basedow, Codification of Private Law in the European Union: The making of a Hybrid, 1 EUR. REV. PRIVATE L. 35-49 (2001). Along this line see "The freedom to bind oneself contractually to a future disposition is an important and striking example of this freedom". The role of contract law "is based upon the theoretical perception that a promise and the reliance on it is a basic behavior in human society" at 37 .

${ }^{68}$ See Stefan Grundmann, The Structure of European Contract Law, 4 ERPL 505, 518 (2001).

${ }^{69}$ See Jürgen Basedow, A Common Contract Law for the Common Market, 33 CMLR 1169-1195 (1996).

${ }^{70}$ See Grundmann and Stuyck, An ACAdemic Green Paper on European contract law (2003).

${ }^{71}$ See Brummer v. European Union Treaty, BverfGE 89, 155 (October, 12 1993) translated in English at 1 C.M.L.R. 57 and the contrasting comments by Joseph H. Weiler, The State "über alles." Demos, Telos and the German Maastricht Decision at http://ideas.repec.org/p/erp/jeanmo/p0132.html and Peter Lindseth, The Maastricht Decision Ten Years Later: Parliamentary Democracy, Separation of Powers and the Schmittian Interpretation Reconsidered at http:/www.iue.it/RSCAS/WP-Texts/03_18.pdf. 
them. ${ }^{72}$ In casting light on the procedural guarantees of EC law, they advocated for a European codification in tune with the functioning of the single market and for legislative discretion by supranational institutions. These jurists often share a common intellectual tradition, which can be traced back to the Freiburg ordoliberal school, which goes also under the rubric of German neo-liberalism, ${ }^{73}$ founded in the 1930s. In drawing on the ordo-liberal intellectual tradition they traced back the meaning of notions such as contractual freedom to the post WWII economic compromise of the German social-market economy. The ordo-liberal tradition offered to the integration project an influential model of legitimation through the notion of the "economic constitution". In relying on the central tenets of the ordo-liberal tradition, jurists perceive the European economic constitution enshrined in the Treaty as a means to ensure greater individual autonomy within the internal market. In arguing in favor of a European codification, they are attempting to provide a framework of general contract rules that will ensure equal possibilities to all players in a free market and create a system of undistorted competition. ${ }^{75}$

In the late 1980s the Commission was in search of a model for drafting the future Unfair Terms Directive. ${ }^{76}$ The Commission relied to a great extent on the German law regulating unfair contract terms. The AGBG (Gesetz zur Regelung des Rechts der Allgemeinen Geschäftsbedingungen) was adopted in 1976 by the Federal German Republic to regulate standard forms agreements. The AGBG aimed to achieve a fair balance between conflicting interests in order to provide a level playing field for private actors and reinvigorate the principle of freedom of contract. $^{77}$ The AGBG already contained all those rules that characterize the unfair terms directive adopted in 1993, such as the principle of good faith and the black list of unfair clauses. Most interestingly, it included a preliminary exception that excluded the application of both provisions when there was an individual agreement over a contract. The AGBG was adopted as a provision intended to regulate economic transactions between industry and consumers and aimed at

\footnotetext{
${ }^{72}$ See Ernst-Joachim Mestmäcker On the Legitimacy of European Law, RABELS ZEIT. 58, 615-635 (1994).

${ }^{73}$ See V. J.VAnberg, The Constitution of markets: Essays in Political Economy, at 37 (2001).

${ }^{74}$ See Miguel Poiares Maduro, We, The Court (2000).

${ }^{75}$ See Christian Joerges, What is Left of the European Economic Constitution, Jean Monnet Paper (EUI 2004) at 12; see alsoDavid Gerber, Constitutionalizing the Economy: German Neoliberalism, Competition Law and the "New" Europe, 42 AM. J. OF COMP. L, 25 (1994) and KERRY RITTICH, RECHARACTERIZING RESTRUCTURING at 112 (2002).

${ }^{76}$ See Unfair Terms Directive, supra note 10.

${ }^{77}$ See Ludwig Raiser, Das Recht der Allgemeinen Gaschäftbendingungen (1935). For a comparative overview see Umberto Morello, Condizioni Generali di Contratto, in DIGESTO DELLE DISCIPLINE CIVILISTICHE at 357 (2001).
} 
giving greater certainty to a consistent body of jurisprudence. German scholars had long advocated for policing the imbalances and inequalities in adhesion contracts. In particular, the AGBG is associated with Ludwig Raiser, one of the prominent private lawyers in post-WWII Germany. Reiser was committed to the creation of a liberal constitutional paradigm reconstructing the relation between the law, societal values and the economy. ${ }^{78}$

However, the Unfair Terms Directive triggered a lot of discontent for a number of reasons. Those neoliberal jurists who were no longer committed to harmonization per se but began adopting a law and economics approach to contract rules while appreciating the competitive advantages in soft legal regime claimed that by policing the unfairness of contracts, the directive had been "abused" because it created more stringent provisions than the ones contained in the German AGB-Gesesetz. They argued that courts have gained disproportionate power through the black list of unfair terms adopted by the directive since they can void those contract terms they consider unfair. As Roberto Pardolesi highlighted, from an economic perspective the paradox is that in declaring the terms void judges cannot consider the price of the contract or of the term since this is expressly left out from the realm of the directive. ${ }^{79}$ In adopting United States mainstream law and economics insights, neoliberal jurists attacked welfare provisions contained in European directives. ${ }^{80}$ They deployed public choice rationales to undermine the goals of the unfair terms directive, which "may cause inefficiencies rather then curing them". ${ }^{81}$ In drawing on mainstream law and economics insights, they argued that although the directive aimed to protect consumers against unfairness, in reality it raised potential causes for inefficiencies, thus creating negative welfare implications. ${ }^{82}$

The Unfair Terms directive also received sharp critiques from those jurists advocating for a welfarist approach to private law and distributive justice in contract law. These scholars argued that contract law should abandon a procedural

\footnotetext{
${ }_{78}^{78}$ See Ludwig Raiser, Il COMPITO del Diritto Privato (1990).

79 See Roberto Pardolesi, Clausole Abusive (nei contratti con i consumatori) Una direttiva abusata? Il Foro Italiano, 137-152, at 150 (March 1994).

${ }^{80}$ For a definition of United States mainstream law and economics see Duncan Kennedy, supra at 17. In European private law see Roberto Pardolesi Clausole abusive, pardon vessatorie: verso l'attuazione di una direttiva abusata, in CARDOZO ELECTRONIC LAW BULLETIN, 1995 www.gelso.unitn.it/card-adm/Review/Review.html attacking the unfair contract terms directive and its "shocking black list of standard forms whose common thread is to shift risks from sellers to buyers."

${ }^{81}$ See See Roger Van den Bergh, Forced Harmonization of Contract Law in Europe, Not to be Continued in S. Grundmann, J. StUyck, An ACAdEMiC Green PaPer on European CONTRACT LAW, at 249 (2002).

${ }^{82}$ Peter Van Wijck and Jules Theeuwes, Protection against Unfair Contracts: An Economic Analysis of European Contract law, 9 EUR..J.L. ECON.:73 (2000).
} 
conception of justice and move towards a substantive one. ${ }^{83}$ If the notion of procedural justice entailed the protection of individual rights and market efficiency, they favored a substantive notion of justice in order to achieve an "acceptable pattern of welfare" with fair distributive results. ${ }^{84}$ Moreover their skepticism towards the EC harmonization agenda contributed to their bias toward hard or uniform legislative tools ad the European level, while favoring soft and flexible tools of regulation.

For instance, when analyzing the Unfair Terms directive, social justice advocates began challenging the harmonization of contract law as widely driven by market rationality rather than consumer protection. ${ }^{85}$ Their criticisms focused on the over-emphasis of the directive on internal market as the primary reason for justifying the harmonization of unfair contract terms. ${ }^{86}$ For example, the preamble of the directive highlighted that divergence among national consumer regulations would create a risk of distorting competition. The justification for the directive was the need to enhance competition in products and services across Member States, rather than the need to develop regulations that reflect contractual realities. ${ }^{87}$ Finally, the directive did not touch upon individually negotiated terms nor did it address provisions regarding the contract price. ${ }^{88}$

According to social justice advocates the Community leit-motif in drafting the directive rested on a market efficiency rationale, which aimed to expand consumer choice. They pointed out that the directive described buyers shopping for their best contractual terms across Member States and assumed that consumers would be better off through greater competition among contractual terms. They remarked that the Commission assumed consumers to be actively involved in

${ }^{83}$ See Hugh Collins, Distributive Justice through Contracts, 45 Current Legal Probs. 49 (1992).

${ }^{84}$ See H.Collins, D.CAmpBell and J.Wightman, Implicit Dimension of CONTRACT, at 11 (2003).

${ }^{85}$ See Hugh Collins, Good Faith in European contract law 14 O.J.L.S. 229 (1994).

${ }^{86}$ The Recitals in the Preamble of the Unfair Contract Terms Directive focus predominantly on the need to develop the single market and establish harmonized ground rules. See Recitals 1, 2, 3 and $5,6,7$ and 8 . This was a way to justify the legal basis adopted by the directive emanating from EC Treaty art. 95, the provision governing the harmonization of the internal market

${ }^{87}$ An analy sis of the Preamble makes it clearly evident that the internal market is the priority. See Social Justice Manifesto, supra note 4, at 235, where he highlights the lack of emphasis in the Preamble to the Directive on the actual consumer contracting process.

${ }^{88}$ See Unfair Contract Terms Directive, Article 4(2) "the fairness of the transaction in the sense of the price paid for the goods or services should not be subjected to review control." In Hugh Collins's view this obscure provision of the directive, by requiring clarity more than fairness, demonstrates how EC contract law is intended for consumer choice and not for consumer rights, see Hugh Collins, supra note 103, at 237. 
gathering and using information to make their decisions. ${ }^{89}$ The directive enlisted contract law as a market-perfecting device, through which properly informed consumers could police unfair terms. ${ }^{90}$

When explaining the stakes of harmonization, jurists put forward three different thesis that share a skeptical view on the European constitutional arrangement: national resistance, subsidiarity and cultural difference. The resistance thesis focuses on the reactions of national legal regimes to the implementation of European directives. ${ }^{91}$ According to this view, the problem of the harmonization of contract law related to the implementation of directives in Member States legal orders, often represented by national civil codes. The different outcomes of the Italian, German and French legal regimes in implementing the Unfair Terms Directive revealed not only the difficulty in harmonizing contract rules but also how little national contract laws were harmonized in practice. ${ }^{92}$ Daniela Caruso claimed that the attempt of the Commission to reform private law through directives has actually engaged state legislators and national courts in resistance against the Europeanization process. ${ }^{93}$

The subsidiarity thesis, based on the principle introduced by the Maastricht Treaty, ${ }^{94}$ focuses on the social dimension of contract law as being inherently national and therefore culturally diverse. Some jurists claimed that contract law couldn't rely on abstract general principles that Europeanization brings with it. ${ }^{95}$ They argued that the Commission should make greater use of the subsidiarity principle allowing Member States to regulate their contract law regimes differently. The subsidiarity thesis has advanced the view that national contract

89 See generally STEPHEN WEATHERILl, European CONSUMER LAW AND POLICy (1997); HowELls G. AND WILHELMSSON, EC CONSUMER LAW (1997).

${ }^{90}$ See Hugh Collins, Good Faith in European Contract Law, supra note 85 at 237. As Collins puts it, there is the consumerist movement which "has percolated into the organs of the EC."

91 See Daniela Caruso, The Missing View of the Cathedral: The Private Law Paradigm of European Legal Integration, supra note 42.

${ }^{92}$ See $I d$. at 104. Daniela Caruso shows how the Unfair Contract Terms directive struggled in its reception by national legal orders. In particular the Product Liability Directive of 1985 was a big disappointment since Member States took enormous delays in its implementation.

${ }^{93}$ See $I d$.

94 See the subsidiarity principle, art. 5 (ex 3B) TEC: "In areas which do not fall within its exclusive Competence, the Community shall take action, in accordance with the principle of subsidiarity, only if and in so far as the objectives of the proposed action cannot be sufficiently achieved by the Member States and can therefore, by reason of the scale or effects of the proposed action, be better achieved by the Community". This article provides a procedural approach to determining issues of subsidiarity, rather than substantive criteria to apply. See George A. Bermann, Taking Subsidiarity Seriously: Federalism in the European Community and the United States, 94 Colum. L. REV. 332 (1994) and G. de Burca,

95 See Hugh Collins, Transaction Costs and Subsidiarity In European Contract Law, in AN ACADEMic GreEn PaPer ON European CONTRACT LAW, at 280 (Stefan Grundmann and Jules Stuyck eds., 2003). 
law is shot-through with distributive concerns, which are now threatened from above by European market integration. According to this thesis, Europeanization is a formalist process that is suppressing diversity as an obstacle to free trade while it undermines the distributive capacity of national contract law. ${ }^{96}$

Some jurists have advanced a third thesis based on the notion of cultural difference. In highly valuing the cultural diversity among national legal regimes, they demonstrated skepticism about the possibilities of the harmonization process. Drawing on sociological, ${ }^{97}$ cultural, ${ }^{98}$ and linguistic ${ }^{99}$ insights, these scholars were skeptical of the unification of private law regimes, which happened more at the level of declamations than at the level of operative rules. In their view, the harmonization of contract law erased European identities and offered a troubling systematization of contract law without attempting to tackle the fragmentation of legal contexts and the dilemmas of the welfare state. ${ }^{100}$ Scholars adopting the cultural difference thesis generally argued against Europeanization as a formalist threat to preserving the cultural tradition inherent in local or national contract law regimes. ${ }^{101}$ In contrast to the various soft approaches, a new slogan proposed in 2002 was "Hard Code now!" 102

\section{The Social Justice Manifesto and the Legitimacy of the Process}

In 2004, a number of jurists advocating for social justice in European private law drafted a Manifesto to address the concerns of citizens about a European civil code "as an expression of cultural identity and a scheme of social justice for a market order." 103 In their intellectual enterprise, these jurists embraced the idea that the new European legal culture offers a possibility to escape from the formalism of private law regimes, allowing for a more open and frank dialogue on the political and social stakes of the Europeanization process. ${ }^{104}$ In sharing a realist understanding of contract law, they drafted a Social Justice Manifesto to

${ }^{96}$ Hugh Collins, Good Faith in European contract law, supra note 85.

${ }^{97}$ Gunter Teubner, Legal Irritants: Good Faith in British Law or How Unifying Law Ends Up in New Divergences, 61 MoD. L. REV. 11 (1998).

${ }^{98}$ Pierre Legrand, European Legal Systems are not converging, 45 INT'L \& COMP. L.Q. 52 (1996).

${ }^{99}$ See LeS MULTIPLES LANGUES DU DroIT (Rodolfo Sacco ed., 2001).

${ }^{100}$ See Thomas Wilhelmsson, Welfare State Expectations, Privatization and Private Law in From Dissonance to Sense: Welfare State expectations, Privatization and Private LaW (T.Wilhelmsson and M. Hurri eds., 1998).

${ }^{101}$ Pierre Legrand, La Leçon d'Apollinaire in C. JAMIN AND D. MAZEAUd, L'HARMONIZATION DU DROIT DES CONTRATS EN EUROPE, at 37 (2003).

${ }^{102}$ See Ugo Mattei, Hard Code Now!, 2 Global Jurist Frontiers 1 (2002) for whom a European Code will benefit consumers, avoiding soft law measures as the product of corporate interests.

${ }^{103}$ See Social Justice Manifesto, supra note 4 at 655.

104 See Martijn W. Hesselink, The New European Legal Culture (2001). 
oppose the notion that drafting a civil code should be a "technical problem to overcome by experts." 105

Rather than a technocratic enterprise based on neutral principles such as freedom of contract, Social Justice advocates envisaged European contract law as a set of doctrinal rules chosen to advance fairness and distributive justice. ${ }^{106}$ They emphasized that the harmonization of contract law needs to be understood as part of European multi-level governance creating political consequences for citizens of the Union rather than merely a tool functional to the completion of the internal market. In opposing a technocratic approach to harmonization, they departed from those suggesting resisting harmonization of contract law because the European level is pervaded by a constitutional asymmetry.

Thus Social Justice advocates claimed that the unification of private law proceeds as part of the political evolution of the construction of the European Union. Therefore the Commission should address socio-economic values more openly and democratically through "new methods for the construction of this union of shared fundamental values (which include respect for cultural diversity) as represented in the law of contract and the remainder of private law." ${ }^{" 107}$ Finally, in their plea for greater social justice and regulatory legitimacy they maintain:

"Unless a more democratic and accountable process is initiated, there is a clear danger that these fundamental issues will never be openly addressed, and a serious risk that powerful interest groups will be able to manipulate the technocratic process behind the scenes in order to secure their interests at the expense of the welfare of ordinary citizens."

The Manifesto starts from the assumption that the Commission, in its regulatory agenda, lacks a vision of fairness, because "[a]s traditionally understood, the function of the European Community is to promote a free market, not to ensure that this market is corrected in the light of distributive aims." 108 The three ideas around which the Manifesto unfolds are fairness in contractual relations, the constitutionalization of private law and the legitimacy of European modes of governance. As to the notion of fairness and the distributive effects of contract rules the Manifesto suggests following the examples of national private law systems, in which the protection is based "upon social needs rather than equal

${ }^{105}$ See Hugh Collins, Editorial: the Future of European Private Law: An Introduction, 10 EuR. L.J. 6, 650 (2004); Social Justice Manifesto, supra note 2, at 655.

${ }^{106}$ See Hugh Collins, Regulating Contracts (1999).

${ }^{107}$ See Social Justice Manifesto, supra note 2, at 657.

${ }^{108}$ Id. at 662 . 
opportunities, or a concern about the distributive consequences of legal rules between groups, such as creditors and debtors, and equally importantly, within such groups." 109

While the neo-liberal agenda fosters clearly conservative goals, one may also criticize from the left the Social Justice Manifesto. For instance, the Manifesto emphasizes the need of procedural legitimacy -understood as a more democratic and participatory processes for European decision-making - in the construction of European private law. While legitimacy is certainly a necessary condition for reaching social justice through the law, one might doubt that it is sufficient. A process can be politically legitimate but lead to anti-social outcomes, should for example, a conservative ideological platform take over in the political process. Despite this possibility, the political choice to intervene in the landscape of European law with any reform proposal capable of handling (paradoxically even to choose) the current neo-liberal drift is welcome as a frontal challenge to the phenomenon of naturalization of the status quo typical of the post-modern condition. ${ }^{110}$

The Manifesto however has only mildly challenged the most influential part of the lawyer's profession, which has a stake in the current equilibrium of power by controlling the lion's share of the European funding to scholarly projects. Not surprisingly a few months after the publication of the Manifesto some of its authors have themselves obtained rewarding sums from the Commission to carry on social justice work while keeping participating in the Von Bar group. This multiple role played by elite academics is indeed a recurrent pattern within the social structure of European private law. As a consequence European private law scholarships is characterized by both the fragmentation of scholarly groups and the formation of grand coalitions pulled together for instrumental purposes, thus creating the phenomenon that we call the Scholarly Industry. $^{111}$

5. The Scholarly Industry and its Dark Sides

It is now worth devoting a few thoughts to European academic legal scholarship, a very important component of the patchwork of European private law in the making. As it is well known, legal scholarship has played a pivotal role through the history of European private law at least since the renaissance of legal studies

\footnotetext{
${ }^{109} I d$. at 666.

110 See the" naturalization effect" in adjudication in DUNCAN KENNEDY, A CRITIQUE OF ADJUDICATION (1997).

${ }^{111}$ For a brilliant analysis on this subject by an anthropologist assessing the economic and symbolic power of each group within the field of European private law, Agnes Schreiner, The Common Core of Trento, A Socio-legal Analysis of a Research Project on European Private law, at 125-140 in A. JETTINGHOFF AND H. SCHEPEL, IN LAWYERS' CIRCLES (2004).
} 
in Bologna early in the eleventh century. Comparativists have observed that in the Western Legal Tradition academic scholars thrive and blossom as "hidden law givers" $" 112$ particularly in times in which the official authority of law is declining or where the law presents itself as divided and in need of some rationalization. In the United States, Justice Cardozo noticed a similar phenomenon when he observed in the nineteen twenties that "the perplexity of the judge becomes the scholar's opportunity." "It is no surprise, therefore, that the highly complex relationship between official producers of private law in present day Europe would produce such an opportunity that some European academics would quickly seize.

Elsewhere, we have described the variety of "professional projects"114 that might have motivated the academics that have taken a critical position towards European codification, an issue that we do not wish to re-open here. ${ }^{115} \mathrm{We}$ are now interested in moving a step forward by observing a more pervasive phenomenon that can be better understood as the role of the bourgeois European legal academia in the production of the ideological component of an hegemonic project. Building on Gui Debord, ${ }^{116}$ one can observe that in the production of the "spectacle" (or, if we prefer, an aesthetic of European private law) determining the limits of acceptable discourses, ${ }^{117}$ both the authorities participating in its construction and those that became authorities of its critique, play a similar role. Consequently what we are observing is independent from the euro-friendly or euro-skeptical positions of the different legal scholars active in the field. Both groups share a belief in the culturally-legitimized and thus respectable, and even desirable, nature of professionalized private law, thus regarding the Western Legal Tradition as a cultural path and as a domain of knowledge of which Europeans should be proud. If, to the contrary, one observes for just a moment, European private law as a "social practice" (or better as an aggregate of social practices) belonging to a dominating social class and serving, by the building of an ideological superstructure, the economic base of current (European) capitalism,

\footnotetext{
${ }^{112}$ See Antonio Gambaro, Il Successo del giurista, Il Foro Italiano (1983); see also J.P. Dawson, The Oracles of the Law (1968).

${ }^{113}$ See Benjamin N. Cardozo, The Nature of the Judicial Process (Yale University Press 1921).

114 See Magali Sarfatti-Larson, The Rise of Professionalism: A Sociological Analysis (Univ. of Cal. Press 1979).

${ }^{115}$ See Ugo Mattei, The European Codification Process: Cut and Paste (Int'l Law Publ'n 2003).

${ }^{116}$ See Guy Debord, The Society of the Spectacle (Donald Nicholson-Smith, trans., Zone Books 1995) (1968).

${ }^{117}$ See Pierre Shlag, The Aesthetics of American Law, 115 HARV. L. Rev 1047 (2002). but more critical in a vein symilar to that of this paper, Haether Huges, Aestetics of Commercial Law. Domestic and International Implications forthcoming.
} 
the attitude towards its desirability is bound to change. One then should then see European private law today (thus letting aside its more general historical role in Western imperialism and plunder) largely as the product of an anti-law movement, aimed at dismantling the concession that through time the law has been compelled to grant to subordinate classes at the advantage of an outright return to a "far west" or unregulated market behavior.

Such an anti-law movement is at play, produced by exactly the same global actors, both in the United States and in Europe (and the other periphery). Clearly its effectiveness in de-civilizing the law is in direct proportion to the weakness of the formal and informal institutional background in which it operates and the resistance that it is likely to find in the institutional setting. ${ }^{118}$ In the United States, the anti-law movement is busy, among many other things, preaching for the lowered punitive damages, the reduction of the role of the civil jury. It is also behind the construction of the law and economic and ADR scholarly industries. ${ }^{119}$

The strategy, exposed by Laura Nader in her ground-breaking work on "harmony ideology," works as follows: an idea, loaded with positive meaning is identified which may be a good cure for a social problem. We do not need to spend time here on the issue of whether the "lack" that the idea is attempting to cure is real or invented. ${ }^{120}$ The example discussed by Nader was that of Alternative Dispute Resolution, but there are a variety of others, such as, for example, the idea of "development", that of "international human rights" or that of "efficiency." Such ideas are usually broad, vague and difficult to challenge: who would argue against the fact that justice should be easily available, that poor countries should be made better off, that human rights should be respected, that it is better to organize something in an efficient way or, by the same token, that one should love mom? Around that idea an intellectual movement of scholars producing work in the area is identified by useful promoters of that idea as an ideology serving a hegemonic project. Their work is consequently encouraged, promoted to mainstream status by the usual patterns of academic prestige, and directly or indirectly funded. Usually the phenomenon does not remain at the academic level; rather, the scholarly work organized and institutionalized as an industry get used by a variety of policy functions. The industry thus grows, develops its patterns of prestige and leadership, its canon, its aesthetics, its foes and its friends. Nader has shown the phenomenon in the birth of the ADR industry, promoted as a challenge to the civil rights movement in the late sixties,

118 In the sense used by Douglass C. North, Institutions, Institutional CHANGE AND ECONOMIC DEVELOPMENT (Cambridge Univ. Press 1990).

119 See LAURA NADER, THE LIFE OF THE LAW (2001)

${ }^{120}$ For example, the litigation explosion that originated the ADR frenzy in the US has been largely invented. See Marc Galanter, The Day After the Litigation Explosion, 46 MD. L. REV. 3 (19861987). 
and now powerfully at play through the world. It is quite easy to see the birth and flourishing of an International Human Rights industry, promoted and organized by Western NGO's, highly instrumental in the construction of non-western inferiority and in the ethnocentric promotion of Western values in such things as gender relationship or family arrangements. Similarly law and development, started as an industry during the cold war, has declined but is now back on its feet, again playing a significant anti-law role in its participation to the Washington consensus version. $^{121}$

One of these authors has identified the development of an "industry" in the transformations of the "Law \& Economics" movement, now pivotal in the policymaking of the International Financial Institutions. ${ }^{122}$ Some of its mainstream antilaw work, attempting to limit the bite of punitive damages, is now financed openly and shamelessly, by gross polluters such as the Exxon Corporation. ${ }^{123}$ This scholarly industry, extremely powerful and well funded in the U.S. and abroad, de-legitimizes the role of the law as a tool of control and constraint to free market activity. Moreover, it aims to capture political and legislative processes under the claim of neutral and efficient rules, improving wealth maximization in market economies. ${ }^{124}$

Once a scholarly industry is organized and promoted in the law, the individual academic active in the field of inquiry occupied by the industry is irresistibly attracted to it. Being internal to the industry offers career and consulting opportunities for oneself and for his or her students and even the policy perspectives stemming from it are attractive for the true believers and insiders. They thus develop loyalties and in little time radical critiques and exposing mode are marginalized and silenced. True, bourgeois academic industries pride themselves of being open and pluralistic. Scholars are not censored. Rather they tend to self-censor. The industry becomes itself a strong "cultural" support for projects of hegemony and domination, and within the industry the fundamental conception of the law as a civilizing device capable of promoting order and freedom is part of the social contract. Truly anti-spectacular critiques stemming

\footnotetext{
${ }^{121}$ See La Porta, R., López de Silanes, F., Shleifer, A. and Vishny, R.W. (1998) Law and Finance, Journal of Political Economy, 106: 1113-1155 and La Porta, R., López de Silanes, F., and Shleifer, A. (1999) Corporate Ownership Around the World, Journal of Finance, 54 (2): 471-517.

122 See Ugo Mattei, The Rise and Fall of Law and Economics: an Essay for Judge Guido Calabresi, 64 MD. L. REV. 220 (2005); see also JAY M. FEINMAN, Un-MAKING LAW: THE CONSERVATIVE CAMPAIGN TO ROLL BACK THE COMMON LAW (2004).

${ }^{123}$ See Louis Kaplow \& Steven Shavell, Property Rules Versus Liability Rules: An Economic Analysis, 109 HARV. L. REV. 713, 748-52 (1996).

124 See Jon Hanson and David Josifon, The Situation: An Introduction To The Situational Character, Critical Realism, Power Economics, And Deep Capture, 152 U. PA. L. REV. 129 (2003); Jon. D. Hanson and Kyle D. Logue, Taking Behavioralism Seriously: The Problem of Market Manipulation, 74 N.Y.U. L. REV. 630 (1999).
} 
from a perception of law as a superstructure, to be resisted as the oppressive capitalistic domination that produces it, are perhaps received raising more than one eyebrow. Usually they fall short of reaching the mainstream channels of scholarly communication, the most prestigious publishers, the leading journals. These venues are dominated by "true" insiders and the rejecting letters will always be on truly "objective" scholarly standards. Most of the time the industry is even able to organize the resistance, in a display of methodological pluralism in the best tradition of the post-modern identity thus occasional critical work might see the light. Nevertheless, if ever critical ideas are published, the books are not promoted and perhaps not reviewed. Insiders to the industry do not like to confront "radical" questions. Harmony has to be preserved. Troublemakers are not welcome.

European private law, much like law and Economics in the United States, today is an industry. It fully participates in what is the truly dangerous radical anti-law movement not just that of a few scholars concerned with equality, struggling for social justice and political transformation. The real anti-law movement today is promoted and supported, by the corporate domination of public spaces. Scholarly industries, determining the space of acceptable speech, contribute in this process of de-legitimization of the traditional political tools potentially capable of being used to control economic processes: the positive law produced by sovereign States. The industry of European private law shares with that of Law and Economics (and with the other industries glanced above) its crusade against the political-based production of law. Anti-positivism turns into anti-state and anti-state into anti-law. The baby is thrown away with the bathwater.

In the European Union, the political actors in the corporate anti-law movement are the same as those in the United States, but the target and the means are different. While the target are the Member State legal systems, with their incremental development of institutional systems of "social" private law (protective formalism, mandatory law, notarized acts, measures of contractual justice such as the broad use of "unconscionability" or good faith) the mean is the creation of another industry, the so-called new European private law. Because the transformation of scholarly movements into industries precludes critical thinking, the consequence of this move is the incapacity to set an independent agenda but rather the desire to follow that of corporate-captured Brussels, in the hope of obtaining funding and prestige. The emphasis on "contract" as the privileged tool of the European private law process is no small part of such hegemonic agenda ${ }^{125}$.

\footnotetext{
${ }^{125}$ An organization that has fluorished to this purpose is SECOLA, the Society for European Contract Law that has been highly instrumental to the present focus on a contractarian vision of the European legal landscape. See their site www.secola.org. Their most recent published effort is S.Grundmann \& D. Mazeaud, General Clauses and Standards in European Contract Law (2006).
} 
The "contractualization" of the legal and political spaces, in fact, has opened new venues for neo-liberalism, suggesting a flexible order in which rights and secured positions are abandoned to the market logic.

While both approaches have been saluted as widely needed challenges against obsolete legal formalism and positivist approaches to legal reasoning, in both contexts they ended up as an ideological legitimazion of the new global legislators. In the United States efficiency functioned as the key element of success of the anti-law movement by endorsing its neo-liberal policies. The transformation of European private law scholarship into an industry has been a successful strategy by which Brussels has both selected it neo-liberal allies (Lando, Von Bar etc...) and has, so to say, "organized" the resistance. ${ }^{126}$ In fact, the Commission founded a "network of excellence" by including together with its neo-liberal expectations also some of the social justice concerns portrayed by the Manifesto. ${ }^{127}$ The Network of excellence has the task of drafting the Common Frame of Reference in which the neo-liberal allies of the Commission have an important role in driving the process. ${ }^{128}$

Many socially concerned scholars avoid asking fundamental questions such as whether capitalism can be reformed incrementally, eventually leading to some idealized state of sustainable development ${ }^{129}$. Many of such scholars, perhaps even believe that the private law system can play a role in this reform. They seem oblivious to the fact that such a belief compels European law to follow an agenda established by hegemonic actors, with no interest in legal civilization, but rather with a clear agenda of dismantling what is left of it. We argue here that an incremental transformation towards a progressive dimension in private law is impossible (while perhaps a gradualist strategy cannot be excluded), that there is a need of a frontal challenge, and that at least an independent leftist agenda should be established.

\footnotetext{
${ }^{126}$ See Ugo Mattei, Basic First Please! A Critique of Some Recent Priorities shown by the Commission Action Plan, 297 in A. HartKamp et Al., Towards A European Civil Code (2 ${ }^{\text {nd }}$ ed. 2004).

${ }^{127}$ See Network of Excellence under the Sixth Framework program of the EC.

${ }^{128}$ See Martjin Hesselink, Capacity and Capability in European contract law, 4 ERPL 491, 494 (2005).

${ }^{129}$ See for a critique, Serge Latouche, Sourvivre Le DEVElopement (2005).
} 
Global Jurist, Vol. 7 [2007], Iss. 1 (Frontiers), Art. 2

\section{Social contract law and Social Europe, part of the problem or part of the solution?}

1. The "Social" Critique of Formalism in Contract Law and its historical inadequacy

To be sure, the meaning of the word "social" in legal matters is much more complex and endowed of a long and ambiguous pedigree in private law, than the recent and quite feeble resurgence of a political sensitivity in the debate on European private law would suggest. European private lawyers share the "Social" intellectual tradition as a "vocabulary of legal concepts" that underwent a radical shift at the beginning of the twentieth century. ${ }^{130}$ Duncan Kennedy, himself associated with the Social Justice Manifesto, nevertheless considers the "social" as one of the very few general legal patterns that historically have been capable in the past of characterizing a global way of thinking about the law.

Initially, the formalist or mid-nineteenth century approach to contract law was rooted in Kantian philosophy and translated into private law by Savigny through the notion of individual rights as forms of sovereignty "absolute within their sphere". ${ }^{131}$ Private individuals were guaranteed freedom from any interference in the enjoyment of their private rights, which were protected by means of an abuse of deductive reasoning. ${ }^{132}$

At the beginning of the twentieth century, some European scholars elaborated a critique of contractual freedom to break with the nineteenth century will-theory in contact law. ${ }^{133}$ Their approach was based on the social and moral perception that industrialization heightened existing economic disparities, which created unfairness between contractual parties. According to Kennedy, after a first wave of globalization of "classical" legal thought, beginning early in the twentieth century a "social legal consciousness" became capable of globalization, expanding its legal assumption well beyond the French and German academy where, thanks to scholars such as Josserand or Gierke, it developed as a reaction to the formalist thinking of the classical era. ${ }^{134}$ For instance, Jhering's critique of

\footnotetext{
${ }^{130}$ See Duncan Kennedy, Two Globalizations of law and Legal Thought: 1850-1968, 36 SuFFoLK U.L. REV. 631, 635 (2003).

${ }^{131}$ See Franz Wieacker, Storia del Diritto Privato Moderno (1967). This conception of individual rights is traced back to classical legal though of F.C. von Savigny. In case of conflict between two individual rights, legal professors resolved the conflict by deducing a solution from individual rights.

${ }^{132}$ See Duncan Kennedy, supra note 119 (explaining the abuse of deduction in Classical Legal Thought).

${ }^{133}$ See Hugh Collins, The Voice of the Community, 4 EUR. L.J. 407 (1998)

${ }^{134}$ See Duncan Kennedy, supra note 128. Kennedy further posits that the social mode of thought, which characterized the $1900-1950 \mathrm{~s}$, has recently yielded to a third globalization of "americanized" legal thinking. This mode consists of a neo-formalist revival in the law, once more
} 
individual sovereignty brought into question the coherence of legal reasoning, which was no longer as a matter of deductive interpretation but it was rooted in mechanical social causes and moved by human ends. ${ }^{135}$ In the beginning of the twentieth century, some jurists elaborated an objective conception of contract law, which is today a crucial legacy among private lawyers. ${ }^{136}$

If this social perspective on contract law has a multifaceted methodology and it is politically ambivalent, there are at least two elements in its legal language that traveled in time but have radically changed their meaning when developed by the social consciousness at the beginning of the 1900 s once translated in the current European private law debate post-1950s. ${ }^{137}$

A first element of the vocabulary of the social is objectivism in contract law. For "social" jurists, the unfairness resulting from the individualist doctrine of freedom of contract can be corrected by an objective notion of contract, endorsing altruistic values. A contract is no longer based on the subjective intention of the parties, as an expression of their free will, but requires a limitation of contractual freedom to fulfill the objective function of those transactions involving a plurality of social and economic interests. In response to the rapid industrialization and the growing interdependence of social reality in the beginning of the twentieth century, the objective function of contract developed as a doctrine to address inequalities in Western legal thought and to protect disadvantaged groups and minorities through special legislations. ${ }^{138}$ As a consequence, the doctrinal shift still of relevance today is the move from a conception of absolute individual rights to notions of abuse of rights and the limits of contractual freedom as a general limitation of right based approaches. ${ }^{139}$

A second element of the vocabulary of the social in contract law is the strategic invention of solidarity, which characterized the social economy of

understood as a merely technocratic artifact serving the needs of economic expansion rather than those of human civilization and solidarity. In a sense, the "social" has been finally abandoned while a mode of reasoning derived from the social, namely balancing between conflicting policies, is still predominant in current legal thinking.

${ }^{135}$ See RUDOLPH VON JHERING, THE STRUGGLE FOR LAW (1879).

${ }^{136}$ See Duncan Kennedy, supra note 119, "The program of the Social: The social people had four positive proposals: (a) from the social "is" to the adaptive ought for law, (b) from the deductive to the instrumental approach to the formulation of norms, (c) not only by the legislature but also by legal scientists and judges and administrative agencies openly acknowledging gaps in the formally valid order, (d) anchored in the normative practices ("living law") that groups intermediate between the state and the individual were continuously developing in response to the needs of the new interdependent social formation.

${ }^{137}$ See Duncan Kennedy, From the Will Theory to the Principle of Private Autonomy: Lon Fuller's "Consideration and Form", 100 COLUM. L. REv. 94 (2000).

${ }^{138}$ See FRANZ WIEACKER, supra note 131 at 289.

${ }^{139}$ See Louis Josserand, De L'Esprit des Droits et de Leur Relativite: Theorie Dite de L'ABUS DU DROIT (1927), at 386. 
republican states struggling against conservative and revolutionary forces. ${ }^{140}$ The rise of organic solidarity in an increasingly specialized and interdependent society informed the regulation of contract law. For instance, the housing sector after WWI became a "coerced housing economy". "Because of the housing crisis in Europe, governments intervened through rent control legislation that imposed prices and protected tenants against landlords. When rent control regulations were under attack all over Europe in the late 1970s, inducing fear that a regulatory gap would emerge from their dismantlement, Wieacker highlighted that the legislator could still circumvent the problem with a sort of "compensatory move", by introducing a contract law regime which would make it more difficult to terminate the rental contract or by creating subsidies for social housing. ${ }^{142}$

Today, well outside of the original historical context in which the social unfolded in Europe and the United States, what is diffused in the new European legal culture ${ }^{143}$ and the Manifesto might be nostalgia synonymous of a time honored vocabulary which only reproduces parts or misunderstanding of it. ${ }^{144}$ What is needed today is thus a full updating of these seemingly critical notions to the current vocabulary characterized by the challenges of economic liberalization and a "third globalization" of legal thought. ${ }^{145}$

2. The Critique of the Social and its erasure in the Manifesto

There are many possible lines of inquiry that show why the belief in a reasonable, coherent and overall social approach in private law is no longer acceptable without great skepticism. The Social Justice Manifesto has paid no attention to these critiques with the unfortunate result of using the social as a positively loaded notion. This essay provides three of them among many. First there is what Duncan Kennedy inspired by European philosophers and sociologists, ${ }^{146}$ has

\footnotetext{
${ }^{140}$ See JAQUeS Donzelot, L'INVENTION DU SOCIAL (1984) (describing the influence on the social by Emile Durkheim at 77 and the shift in the notion of an organic solidarity founded on the division of labor which increases at the same time specialization and interdependence among individuals), in EMILE DURKHEIM, LA Division DU TRAVAIL SOCIAL (1893).

${ }^{141}$ See FRANZ WIACKER, supra note 122, at 292.

${ }^{142} I d$.

${ }^{143}$ See Martijn W. Hesselink, The New European Private Law (2002) at 170.

${ }^{144}$ See Duncan Kennedy, Thoughts on Coherence, Social Values and National Tradition in

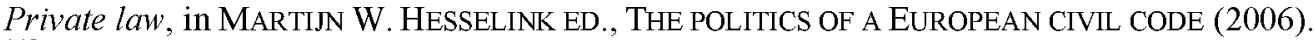

${ }^{145}$ See Duncan Kennedy, supra note 132 (explaining that a third globalization of legal thought is characterized by a new legal consciousness which speaks the language of rights and neoformalism as well as the one of balancing conflicting policy values).

${ }^{146}$ See Max Horkheimer, The End of Reason, in THE EsSENTIAL FranKFuRT SCHOOL READER 26 , 27-28 (Andrew Arato \& Eike Gebhardt eds., 1978); Max Weber and Catherine Colliot-Théléne, Le désenchantement de l'état: de Hegel á Max Weber (1992) (discussing the disenchantment of the state from Hegel to Max Weber).
} 
called the Death of Reason narrative which has pervaded European legal consciousness since the middle of the twentieth century:

"[...] legal consciousness participates in an even more general or abstract history of American thought that in turn participates in a Western story of loss of faith. It is important that loss of faith is something that happens as an event along a rationalizing work path that transforms whatever discourse we are talking about, so that we lose faith (or don't) in reason in a world that has been transformed by reason, rationalized to the point of arbitrariness, so to speak."147

If the Social was a predominant mode of legal consciousness in Europe, this also produced the seeds for its end. Through Weberian disenchantment towards legal reasoning and its increasing rationalization "jurists reconcile with a loss of faith narrative, which denies transcendence and coherence of formal legal rationality while unmasking violence and coercion in the acceptance of legal rules." 148 Thus, rules embedded in the vocabulary and the institutional imagination of the social can no longer provide unquestioned solutions. Rather, the lack of balancing between conflicting interests behind each rule and the unquestioned acceptance of a legal rule instead of an alternative one turns out to be the very core of the inadequacy of a social contract law.

A second critique, addresses the skepticism towards welfarist legislation that in the 1970s legal economists in Chicago articulated clearly and influenced legal thought on both sides of the Atlantic. In their attempt to undermine the possibility of social legislation and their unintended consequences, mainstream legal economists defended the notion that welfare legislation was necessary "hurting the people it was trying to help." In fact, through the increase in prices of consumer goods, sellers could easily pass on the costs of a warranty to the consumers. In this way, the beneficiaries of the warranty would be driven out from the market. For instance, in addressing compulsory terms, which performed an insurance-like function for buyers, mainstream law and economics scholars argued that they created inefficient outcomes by diminishing overall consumer welfare by creating higher prices. The warranty undermined the purpose of reducing transaction costs through contracts of adhesion, while it made worse off marginal groups of consumers that were priced out of the market. Thus, according

\footnotetext{
${ }^{147}$ See Duncan Kennedy, supra note 135 at 98.

148 Duncan Kennedy, The Disenchantment of Logically Formal Legal Rationality, Or Max Weber's Sociology In The Genealogy Of The Contemporary Mode Of Western Legal Thought, in MAX Weber's Economy and Society: A Critical Companion, (Charles Camic, Philip S. Gorski, David M. Trubek eds., 2005).
} 
to these scholars, compulsory warranties in consumer contracts "run counter to redistributive rationales" by creating non-optimal market results. ${ }^{149}$

A third reason to be skeptical of the 'social' stems from the so-called constitutional asymmetry theory. European institutions engaged in centralized private-law reform have often supported the deregulatory process initiated in the late 1970 s by conservative national governments. For instance, the product liability directive managed to lower the standards of protection for consumers in several Member States, especially where these rules were not highly visible because they were created through judicial lawmaking. ${ }^{150}$ From the viewpoint of welfarist advocates, Member State autonomy is severely limited by the new European legal order for the sake of achieving a fully integrated market, and Europeanization threatens to dismantle national social provisions. Because of a "constitutional asymmetry" pervading the EU, neither the Community decisionmaker, nor the Member States have the comprehensive regulatory capacity to undertake a strategic compensatory move to implement reforms or create new contract, administrative or criminal law rules. ${ }^{151}$ Obviously, the faith in the social loses much of its steam if one embraces the constitutional asymmetry theory.

These three lines of critical inquiry suggest departing from the vocabulary of the social in private law. Rather, they strive to find answers to the critiques of the social. Not only progressive projects should articulate these answers but they ought to set aside the "contested concept"152 of social values for their agenda, no matter if social is accompanying words like justice, rights and modes of legal consciousness, that are only contextually meaningful today. Most importantly, in the European context one should give full consideration to the fact that the Network of Excellence of scholars drafting the CFR has included "social justice" into a hegemonic project, that of constructing the private law industry, that is part of the third globalization or imperial Americanization of law. Further it is mandatory to avoid confusing between the social as a scholarly notion intrinsic to

\footnotetext{
${ }^{149}$ Alan Schwartz, A Reexamination of non-substantive unconscionability, 63 Va. L. Rev. 1063, 1058,1067 (1977). The efficiency of standardized contract lies in its internal construction: Once the seller pre-establishes the terms of the contract and the consumer is presented with a 'take it or leave it' agreement. Both buyer and seller thereby avoid further transaction costs of negotiating individual agreements while a legal rule restricting the enforceability of standardized contracts creates large efficiency loss.

${ }^{150}$ See Daniela Caruso, supra note 42.

${ }^{151}$ See Fernanda Nicola, Another View on European Integration: Distributive Stakes in the Harmonization of European Law, in C.DALTON AND D.DANIELSON, PROGRESSIVE LAWYERSING, Rethinking Strategies AND IDEOLOGY (2006); Daniela Caruso, Limits of The Classic Method: Positive Action In The European Union after the New Equality Directives, 44 HARV. INT'L L.J. 331,345 (2003).

${ }^{152}$ Duncan Kennedy, Thoughts on Coherence, Social Values and National Tradition in Private Law, in Duncan Kennedy, , The Disenchantment of Legal Rationality, in THE POLITICS OF A EUROPEAN CIVIL CODE (Martijn W. Hesselink ed., 2006).
} 
private law and the social as a political essence of current Europe, something that we turn to explore now.

\section{Social Europe: A Solution or a Competitive Hegemonic Project?}

With the fall of the Soviet Union the international political field has been constructed as an essentialized end of history. Socialist alternatives have been largely erased (think about the experience of Cuba, or the more recent ones in Venezuela or Bolivia), demonized (North Korea) or reconstructed in westerncapitalists terms (think about China). Non-socialist alternatives have been relentlessly fought (Afghanistan, Iraq, Iran...). Within the dominant West an opposition, that between European social capitalism and Neo-American capitalism has been introduced ${ }^{153}$, emphasized ${ }^{154}$ and accepted as a self-image of many European moderate leftists.

European capitalism has been characterized by a much more social flavour than its United States counterpart. ${ }^{155}$ Should European law be able to capture and reflect in the rules of the game it sets forward some of the values comprised in the "European social model", it might impose itself as a model capable of competing with United States hegemony. Is that a desirable outcome seen from the left? Is a model of gentle capitalism, based on a radically unequal pattern of resource distribution (due to colonial accumulation and double standards in international trade) what we should look forward to?

Across disciplines scholars have articulated the European identity in opposition to the United States model of homologated capitalism. The EU stands as a softer, more diverse and ultimately more social model of market integration. ${ }^{156}$ If the United States stands as a multiethnic melting pot pervaded by racial and socio-economic segregation, the EU stands as a welfare regime, which protects through rights-based and solidaristic multicultural claims its citizens, but not its outsiders. ${ }^{157}$ We should be weary of such flawed oppositions that are aimed to construct capitalism as a sustainable model of development provided some moderate reforms of its most savage distortions are cured. The essence of capitalism is much easier to perceive when it has its gloves off, and one of the

\footnotetext{
${ }^{153}$ This opposition between Rehnan capitalism and Neo-American capitalism has been introduced by the French Economist Michel AlberT, CAPITALISME CONTRE CAPITALiSME (Seuil 1998).

${ }^{154}$ Cf. Jeremy Rifkin, The European Dream: How Europe's Vision of the Future Is QUIETLY ECLIPSING THE AMERICAN DREAM (Polity Press 2004).

${ }^{155}$ See Gros Pietro-Reviglio-Torrisi, Assetti proprietari e mercati finanziari europei, (2001).

${ }^{156}$ See Charles F. Sabel and Jonathan Zeitlin, Learning from Difference: The New Architecture of Experimentalist Governance in the EU, Presentation at the ARENA Seminar, Centre for European Studies, University of Oslo, June 13, 2006; A.AlesinA, Fighting POVERTY IN THE EU AND THE US (2003).

${ }^{157}$ See Etienne Balibar, We the People of Europe (2004), Hauke Brunkhorst, Solidarity, From CIVIC FRIENDSHIP TO A Global LEGAL COMMUNITY (2005).
} 
risks of the social aesthetics is exactly its working as an ideological device masking a reality of hypocrisy, neo-colonialism and exploitation. No progressive agenda should point at an alternative hegemonic model. Hegemony is what should be relentlessly criticized and the real issue, on which it is hard to take side is whether the law can serve or not, at least in transitional, anti-hegemonic purposes.

In departing from these competitive hegemonic views, from a progressive political perspective the possibility of Social Europe is no more than a compromise of realism, but it might at least be a first step in the gradualist construction of a more civilized worldly legal landscape. ${ }^{158}$ A progressive agenda ought to look for solutions by considering the variety of European social models through the awareness that market outsiders, immigrants and those who have no access to business transactions might be the first beneficiaries of Social Europe, should a platform of opening it up become successful. Thus European integration could be seen as a moderate redistributive exercise.

We will pose here only a few questions for discussion that have been largely ignored by European private law serving the function of an industry. Our goal is to tackle those preliminary issues that the scholarly debate should clarify to make political choices possible. Institutions, should serve a purpose. Proposed reforms and changes should create advantages and benefit for the community they serve. The first question to pose is consequently whose interests the European private law system has to serve? Is the European law only to serve the interests of the Europeans? Alternatively, is Europe a sufficiently strong world power (both in terms of economy and of culture) that its legal system can influence global developments in the present moment of high uncertainty about what path we should walk in the future of world capitalism? We submit that European private lawyers should take full advantage of the cosmopolitan perspective stemming from their more cosmopolitan background (which has proved to be a necessity rather than a choice in present day's Europe) to think worldly, i.e. to imagine a legal structure of the European market capable of working as a model and consequently serve the global community and not merely the European interests.

European lawyers, if paralleled with their U.S. counterparts, have been good comparativists but very poor economists and social scientists. This lack of knowledge in other social sciences has for a long period of time closed European lawyers (common lawyers as well as civilians) into a useless black letter style of legal positivistic analysis that made them completely disregard the social and economic impact of their legal constructions. Once the costs of legalism have been understood, at least by some avant-garde (mostly of comparatvists) in a relatively recent past, the poor conditions of the background understanding have not ceased to play a negative role. In the efforts of their kempf against positivism

${ }^{158} \mathrm{Cf}$. Guy Canivet and Horatia Muir Watt, Européanisation du droit privé et justice sociale, $3 \mathrm{Z}$. EU. P. $517-22(2005)$. 
and in the late and hasty discovery of the existence and virtues of the market, many European lawyers (as well as a large number of policy makers throughout the political spectrum) have trusted the virtues of an unregulated market much more than what is in order. Rather than limiting and trimming regulation where wasteful, European legal culture, similar to Law and Economics in the United States, participated in surrendering the political process and its legitimated production of binding rules of behaviour to unrestricted market practices only softly regulated when regulated at all. This trend, to say the least, is based on bad economics.

European policy-makers should not underestimate the potential major impact of what happens today in Europe in the current lawless global corporate marketplace. Many people in the world (including in the United States the many discontents of the World bank and the IMF as global lawmakers) would welcome a truly responsible piece of economic legislation, something that Europe owes to humankind to make good its less than respectable exploitive past. A radically reformed European legal system, prestigious because of the culture behind it, could become, in the global world, a true model provided that mainstream European intellectuals and policy makers stop now their self congratulatory attitude stemming from an ideological construction of our tradition, as if Europe were not in the past and in the present responsible for much suffering and strife in the world. If, as a leading legal system, Europe begins to change its attitude towards lawless capital globalisation in favour of a more progressive and redistributive model of economic development, this could be a first move of countertrend away from global hegemony and exploitation. ${ }^{159}$

4. Social Europe versus Socialist Europe.

Just like in using notions such as "the social" European private lawyers have deployed a term which lost its contextual values and its most sophisticated legal implications, similarly European scholars have plunged into European integration and a "third globalization" with no awareness of their own path in the building of a progressive legal regime. In the last fifteen years a lot has been written on the fall of socialism in the former Soviet Union. A variety of explanations, more or less self-congratulatory, have been advanced but no attempt has been made to shed light on two aspects, both strictly connected, with the present state of European private law. First, no attempt has been made to appraise the positive contribution of socialist and communist scholars to private law in Europe,

\footnotetext{
${ }^{159}$ See Steven Gill and David Law, Global Hegemony and the Structural Power of Capital, 33 INT'L STUD. Q. 475 (1989).
} 
including such diverse experiences as the "Uso alternativo del diritto"160 in the Italian legal academy of the seventies and the East German Civil Code of $1975 .{ }^{161}$ These genuine and ambitious contributions to the development of a more inclusive system of private law have been hastily and unfairly dismissed. Second, no effort has been made to appraise the negative consequences for European law of the fall of the Soviet block. Nevertheless, a clear appreciation of the impact of the release of Cold War pressures on European law-makers after the symbolic fall of the Berlin Wall is the indispensable context for any significant analysis of social trends in European law today.

One can observe in general that private law in Europe, historically unfolded remote from social concerns, the traditional domain of the public law in the civilian taxonomy. Naturally, there have been a variety of early countertendencies in this mainstream attitude to consider wealth disparity and power imbalance as irrelevant to private law. The rich debate on the so called "social function" of rights that occupied the 1930s in Europe witnesses such wealth of thought, spanning from the Second International to the Catholic solidaristic tradition, even reaching some aspects of the so called "fascist conception" of property law. ${ }^{162}$ Even in the mainstream nevertheless, a political platform of equality and an agenda of re-distribution of wealth, mostly but not only located in the public law tradition, has characterized, with different degrees of intensity, the first three quarters of the twentieth century. Such a platform, put at the center of national political processes by the workers and trade union movements, stimulated the growth of the Welfare State institutions, a more or less conscious strategic concession of the industrial bourgeoisie to avoid anti-capitalist revolution. While this social welfare has often been fiercely resisted both from the right (particularly by the more reactionary and authoritarian industrialists) and from the left (challenging social institutions as Foucaultian controlling processes), it is a fact that the weak actors of society have received some material benefits from the birth of welfare state institutions, with consequent increase of human civilization and dignity.

In a number of countries where socialist and communist parties have been able to survive the relentless persecution of Fascist regimes, reaching some degree of power through the Cold War, some local legal scholarship has developed a genuine social dimension, something far more advanced than the "third way"

${ }^{160}$ See Pietro Barcellona (ed.) L' Uso alternativo del diritto. I Scienza Giuridica e analisi Marxista (1973); id vol II Ortodossia giuridica e pratica politica (1973); see also Cesare Salvi (ed.), Categorie Giuridiche e rapporti sociali (1978).

${ }^{161}$ It is therefore particularly important the initiative of Professor Luca Nivarra of the University of Palermo (Italy) that has convened a conference on the legacy of the "seventies" in private law for July 2006.

${ }^{162}$ See K. Renner, Gli Istituti del Diritto Privato e la loro Funzione Sociale (It. transl. 1981); see also David Kennedy, supra note. 
compromise reached in the mentioned Social Justice Manifesto. Consideration should be given to the fact that the Welfare State and more generally the traits of the so called European social (or Rhenan) capitalism developed together with a variety of protective policies and within a strong role of the State into the Member States economies which have been anathema to Brussels from the very beginning of the European Common Market.

The market is healthy when in open competition with other institutions, the legal system and the political process being the most significant. ${ }^{163}$ However the common market should neither be ignored nor made the object of idolatry as the accession in May 2004 signified for many of the new comers to Social Europe in departing from their Socialist and undemocratic past. ${ }^{164}$ The market should be regulated to the extent necessary to make all the actors pay for their social costs. Such regulation, short from coming only from the public law and from ex-ante government authorization, should be rooted in substantive private law rules accessible to everybody and given bite by a variety of effective remedies. This aspect introduces another crucial aspect of a progressive agenda.

The law in the West is an important aspect of the cultural identity of a community. Europe is in desperate need of such an identity building exercise, from the perspective of anybody who is interested in providing a viable alternative to the present, unsustainable, pattern of capitalist development and exploitation. Dismantling the social institutions of capitalism such as access to law for the poor in favor of the return to a laissez faire philosophy (in the name of market flexibility), as it consistently happened since the fall of the Cold War, is not a necessity. It is only reactionary politics.

\section{Setting a Progressive Agenda in European Private Law}

We shall now try to move a first step in the outline of a policy agenda for the purpose of developing methodologies and strategies for a progressive model of private law, radically breaking with the present, unchallenged trends in European private law. Despite the fact that one of these authors has actually participated in the drafting of the Social Justice manifesto, we believe that the time is ripe for a thorough break with its moderate, half of the way, logic. In this light participation in the drafting of the Manifesto back in 2003 should be seen as "gradualist" strategy (in the sense developed among others by Togliatti as early as 1946) while the time is now ripe for its frontal challenge. In a moment of unprecedented acceleration, when government appointed members to the "common frame of reference" are beginning to give institutional life to what only two years ago

${ }^{163}$ See Douglass North, supra note 138.

${ }^{164}$ See David Kennedy, The Tale of Two Architectures, in THe Dark Sides of Humanitarian LAW (1997). 
seemed only an ill conceived idea ${ }^{165}$, the construction of the European private law industry (symbolized by the European Commission- funded creation of the "network of excellence") requires radical critique and production of alternatives now, before it is too late.

The setting of a new progressive (or if you prefer marxistlsocialist) agenda for European private law should start from the full exposure of the "third ways", "end of history", "new labor" logic that dominates the Manifesto, which makes it participate in the "harmonious" logic 166 of construction of the "inevitability" of the current patterns of power disparity, both within the Union and outside of the boarders of fortress Europe. By claiming a "social" exception to the neo-liberal logic, and by making the "social" an alternative to the current model of neoliberal domination, the Manifesto blames the current state of affairs to the technocratic way in which Brussels handles the issue. It moreover implies some moral superiority of the European model of capitalism as opposed to the U.S. one, an assumption that is entirely to be demonstrated and that only serves hiding a higher level of political hypocrisy.

The European third way political logic of the Manifesto, just like the dominant platform of the Democratic Party in the United States, are nothing more than political superstructures in the present phase of global capitalism. They cannot be distinguished among them in moral terms but should be critically appreciated as political allies in maintaining the economic and social status quo and, for what matters here, the system of private law as a tool of decentralized domination rather than of cultural expression and liberation. This strategy of pointing at the responsibilities of some extremes or exceptions, rather than appreciating those of the dominating middle ground is particularly diffused in the privileged social class of jurists who thrive in its business of granting principled legitimization to inequality and exploitation. ${ }^{167}$

Thus the current necessity on the legal left ${ }^{168}$ to face a line of questions that Pietro Barcellona was posing more than thirty years ago and that need some answers in the current transformative phase of European private law: "In what conditions is it possible to be politically active while remaining jurists? What political change is possible to reach with the tools of the law? What are the legal tools that should be preferred in a perspective of (more or less radical) transformation of society?"169

\footnotetext{
${ }^{165}$ See Ugo Mattei, Basics First Please!, supra note 124.

${ }^{166}$ In the sense discussed by Laura Nader, Harmony Ideology, (1990).

${ }^{167}$ See Giorgio AgAmBen, Homo SACER: SOVEIRGN POWER AND BARE LiFe (1998).

${ }^{168}$ For some proposals, in need of beinbg transformed into legal praxis see most recently ROBERTO M. UnGer, What SHOUld 'THE LEFT' PROPOSE? (2006). Unfortunately Unger has given up in recent years the issue of how to transform these proposals into legal action.

169 See Pietro Barcellona, L' Uso Alternativo del Diritto: Ortodossia Giuridica e PratiCa PolitiCa (1973).
} 
These questions point today even more than thirty years ago, at the political necessity of a dramatic discontinuity in the settled balance of power in the dialectic between private law as an agency of market oppression as opposed to an agency of economic and political liberation. ${ }^{170}$ Given the present irresponsible and destructive phase of capitalistic accumulation and development, this intellectual break pointing at progressive alternatives and exploring them into details, should happen sooner rather than later. This article should be seen also as a plea to other "resisting" legal scholars and intellectuals to aggregate around a construction of such alternatives based on a political platform alternative to the moderate one of the Manifesto. At the moment, the social dimension of European private law is almost an oxymoron, if not an alternative model of hegemony, evoked as a aspiration more than as a political platform by a few concerned scholars. Unfortunately, in the present phase, the social mode of European private law only works as false consciousness, offering a degree of respectability to a field, that of European private law, whose DNA is inherently subservient to the requirements of global capitalism.

\section{Re-Politicizing the process}

In an attempt to draft some priorities, a first requirement is that of humblety and a sense of a limit. In general, jurists as such should not attempt to substitute politicians in making choices impacting the general public, so that a first limit of action, that of political legitimacy, as opposed to professionalism should be regained. Contrariwise, private lawyers should be aware and defiant of the traditional limits of their own field. Private law is an institutional structure born in Europe out of requirements of early capitalistic accumulation, itself functional to the early imperial transformations of the Roman Republic and of Renaissance colonialism. It is possibly the area of law most compromised with and intimately related to capitalism, so that its anti-capitalistic and counter-hegemonic use is the most problematic. In setting the agenda of a progressive legal and political platform, therefore, private law jurists should stretch their reach to the boarders of the traditional subject matter. We need, on the one hand, to reinstate the limits of law as opposed to political action. But on the other hand we need to bluntly overcome the limits of traditional private law as an agency facilitating accumulation and exploitation, to occupy and integrate in the fundamental structure of property rights (which certainly includes contracts and torts) those more progressive areas dealing with individual welfare and rights of the lower classes as opposed to the exploiting elites. What should be our attitude in front of the ownership, individual or corporate, of means of production? What limits should we set to economic rights and freedoms? Should we work out a full theory

${ }^{170}$ This dialectic is explored in details in Ugo Mattei \& Laura Nader, Plunder. Imperial Uses of the Rule of Law, forthcoming. 
of rights abuse able to confront arguments fearing the dictatorship of courts of law? How can we civilize corporate behavior?

While we do not think that the decision on whether to attempt a comprehensive reform of European private law (possibly inspired by values of social justice) and the choice of values informing this reform should belong to professionals, we believe that the legal left should work out detailed proposals on issues such as the ones touched in the previous, incomplete, list of questions. The decision of whether to change the law is a core business of the political process. But the political process should be put in the position to evaluate technically sustainable alternatives to avoid reproduction of the kind of mistakes that have produced failures of socialist alternatives in a variety of political contexts.

True, in the quite short history of the European Union most major choices have been carried on by technocrats and imposed over the people. Possibly the creation of a Euro zone is the most important of those. Nevertheless, the lack of participation in the adoption of EC legislation that is plaguing Europe and the consequent resistance in the adoption of a European Constitution imposed from the top down should not be seized by influential professional guilds (such as that of academic lawyers) to claim privileges and powers that clearly do not belong to them. The spirit of the European people and of the working class majority should be able to emerge in a genuine popular constitutional effort in which the wind of socialism might once more blow, if for no other reason because of the miserable state of affairs produced by current neo-liberal trends. It is the province of progressive jurists, to expose the contradictions of democracy double talk disempowering the people by skilful use of ideology.

A master of progressive private $1 \mathrm{aw}^{171}$ has already suggested the need to appoint a politically responsible body to revise and suggest reforms in the domain of private law, authoritatively developing a suggestion that one of us has also hinted to sometime ago. ${ }^{172}$ Struggling to obtain such a politically legitimized and responsible body, perhaps on the model of the British Law Commission, looks like an unavoidable pre-requisite to allow the socialist component of European private law culture to impose its alternatives imperio rationis. Giving back the political choices where they belong and taking them away from technocrats and self appointed academics, certainly aids in understanding priorities. Moreover a legitimate process will prevent that the mode of soft influence exercised by corporate actors and will set the next agenda on European Private Law. One of the most interesting (and dangerous) ways in which the agenda is set is by transformation of otherwise critical modes of thought (as for example independent scholarship on European private law) into organized, quasi political "industries",

\footnotetext{
${ }^{171}$ Stefano Rodota', Il codice civile e il processo costituente europeo, 23 RIV. CRIT. DIR. PRIV. 21 (2005).

${ }^{172}$ See Ugo Mattei, The European Codification Process, supra note 114.
} 
where scholars carry on a political platform, and develop stakes and loyalties to their collective "accomplishment", abandoning any critical doubt whatsoever.

Martijn Hesselink has been one of the most prominent voices among the moderate scholars of the Social Justice manifesto advocating for a repoliticisation of the process of adoption of a European contract code. ${ }^{173}$ In looking at the past difficulties in implementing private law directives Hesselink is sceptical of the possibility of adopting by 2009 a comprehensive Common Frame of Reference as the Commission aims to achieve. ${ }^{174}$ However, in looking at the example of the Dutch Civil code adopted in 1992 he suggested that the Commission should submit, similarly to the Dutch commission in the 1950s, a list of questions regarding the substance of the Common Frame of Reference to the European Parliament. This has been one of the possible strategies proposed by scholars to re-politicise the process of Europeanization of private law by making it more public and less technical.

It is true that many of the issues to be faced in the "making" of private law are of a somewhat "technical" 175 nature, so the public understanding of their political implications can be only limited. Nevertheless, it is extraordinarily important for at least the scholarly and legal communities at large to be aware of the fundamental political implications of the different options. This is particularly crucial these days when a large variety of discourses and rhetorical devices are acritically imported from the United States either as trendy cultural movements, or as self-serving solutions imposed or marketed by the all mighty transnational economic actors together with their faithful servants - the mega-law firms and, more generally the mainstream legal community.

But once the political dimension is understood --- and the Manifesto has certainly been useful from this point of view--- the issue of the leftist political agenda is entirely to be faced and, as we hope we have been able to explain, the word "social" might well be more part of the problem than of the solution.

\section{Toward a Transformative Agenda for European Private Law}

European private law has many lessons to learn from the past in order to accomplish the challenges for the future and to be transformed for the purposes of a progressive agenda. To begin with it is imperative to overcome the great abyss between the common law and the civil law traditions in order to profitably learn from both experiences. Reform should reflect contributions from all the legal traditions of Europe, and we would suggest, also from those non-European

\footnotetext{
${ }^{173}$ Martijn W. Hesselink, The Politics of a European Civil Code, 10 Eur. L.J. 675 (2004).

${ }^{174}$ Martijn W. Hesselink, The Ideal of Codification and the Dynamics of Europeanisation: The Dutch Experience, 12 EuR. L.J. 279 (2006).

${ }^{175}$ See, however, David Kennedy, The Political Stakes in Merely Technical Issues of Contract Law, 10 Eur. ReV. Private L, 7 (2002).
} 
traditions that a ripe community of legal scholars well grounded in comparative law, might be understood as useful for the task of legal civilization. This is why, in the domain of European private law, a progressive agenda should make al the possible efforts to give voice to the traditionally recessive legal cultures, (the Latin as well as all the new accessions), today plainly ignored or treated with condescendence in all the so called "integrative" projects of European private law making ${ }^{176}$

European legal scholarship (or science as once was said) should learn to think more freely, should break the still present cages of formalism, should challenge the established taxonomies and all the artificial boundaries like those between private law and public law or between substantive and procedural law. The task in front of us is to produce a restructured private law system capable of becoming the milestone of twenty-first century social and political regulation of market forces. We are in need of a regulation of market transactions capable of making them serve the interest of everybody not only of strong economic actors nor, of course Europeans only. Such an effort, which is clearly the province of an inclusive leftist agenda, must be started before it is too late.

Many things that traditional formalist (particularly civilian) cages of learning have precluded from being considered as top priorities in private law should be approached and thoroughly explored. Remedies, access to justice, environmental law, protection of diffused interests, fundamental antitrust regulations and many other connected fields should all be thoroughly explored. A process of socially concerned European law reform is an exercise of learning by doing. It is however an exercise that needs to be done within a conscious political plan to accomplish the result.

A minimalist effort should be to locate those fundamental principles that can readily be used by courts to force market actors to internalise the social costs that they produce and transfer on weaker actors. This is why limiting the focus on contract law, as it is the trend legitimized by the Social Justice manifesto, is both a mistake and a hegemonic strategy to be denounced. The outcome is to even more openly shift private law to the service of global market capitalism. ${ }^{177}$

Even seen from the more conservative perspectives of social sciences, and of economics in particular, private law is an integrated body of fundamental rules

\footnotetext{
176 This claim is developed in Opening Up European Private Law (M. Bussani \& U. Mattei eds., 2006) For some information Christian Von Bar \& Stephen Swann, Response to the Action Plan on European Contract Law: A More Coherent European Contract Law (Com 2003, 63), EuR. REV. PRIVATE L. 595 (2003).

${ }^{177}$ See M. Bussani, The Contract Law Codification Project in Europe: Policies, Targets and Time Dimensions, in AN ACADEMIC GreEn PAPER ON EuROPEAN CONTRACT LAW (Grundman \& Stuyk eds., 2004)
} 
of the game ${ }^{178}$. Contracts, torts, property, restitutions and corporation in this perspective play a very similar role. They integrate and complete each other, as private law rules introducing correct sets of incentives for a market place in which the social costs are appropriately internalized. Variations in form might be substantial. They are however the resultant of historical accidents (sometimes promoted as legal culture but that could be described more critically as survivals in the sociological tradition or path dependency in the economic one) that do not change the fundamental substance ${ }^{179}$. The truth of the matter is that taxonomy in the law must only serve the purpose of organizing knowledge and should never be seen as something determining the substantive solution to social problems. For too many years European lawyers (again in the Continent as well as in the common law) have been victims of the illusion that deducting (or inducing) rules from taxonomy could be seen as a scientific exercise. Such formalistic exercise has only been a waste of time but has many times guided ill-considered decisions.

For some years now a project known as The Common Core of European Private Law has been carried on as a painstaking effort to understand how things really are in European private law ${ }^{180}$. Our efforts have been conscious of the many difficulties and epistemological objections that we were facing. Nevertheless, our experience has been that taxonomy, is bound to become a cage if any attempt is made to use it beyond its very minimal (but so important at the same time) task of organizing materials. As long as the law contains a regime comprehensive enough to force at least internalisation of social costs, any taxonomy works. Alternatively, the purest taxonomy will contribute zero to legality and legal civilization.

One important lesson that we can learn from social sciences and from the most advanced approaches to legal scholarship is the importance of the dynamic process, in the production of institutions as well as of technology and products. The processes as well as the outcomes should attract the attention of scholars, judges and legislators. Most of the externalities, most of the social costs dumped in the backyard of our weaker neighbours of the south of the world, are created during the process of production of commodities that are vastly consumed by the almost half billion people that make the European market. ${ }^{181}$ Such process of production is traditionally simply ignored by private law, concerned as it is only with the final outcomes. This state of affairs simply shows that European

\footnotetext{
${ }^{178}$ See R. Cooter, Towards a Unified Theory of contract Property and Tort. The Model of Precautions, 73 CAL. L. REV. 1 (1985).

${ }^{179}$ A full fledged critique of the conservative use of the idea of legal culture can be found in Ugo Mattei and Anna di Robilant, The Art and Science of Critical Scholarship. Postmodernism and International Style in the Legal Architecture of Europe, 75 TUL. L. REV. 1053 (2001).

${ }^{180}$ See Bussani and Mattei, The Common Core Approach to European Private Law, 3 CoL. J. EuR. L. 339 (1997).

${ }^{181}$ See for a fascinating discussion of such process of externalisation, N. Klein, No Logo (2000).
} 
consumers pay too little for their commodities since their prices do not reflect the true social costs of production (environment, labour exploitation, etc.) and European capitalism is once again subsidized by former colonies. Moreover multinational corporate logo-lords (mostly European and North American) make unfair profits pocketing the value of such social cost. In both cases such economic realities should be a concern for the European policymaker when busy drafting the rules of the game. It is the duty of a progressive agenda to expose this lack of attention. To be sure, we know that a large number of successful market competitors on the European market offer an inefficiently high number of products at an artificially low price. Such multinational competitors push out of business smaller market actors. Smaller market actors do not externalise costs of production on people in the south of the world. Usually by acting locally such weaker actors have to comply with European standards of labour conditions and environmental protection and, as a consequence, cannot supply as many commodities at such law prices. Producer's liability, one of the frontiers in European private law, only covers social costs imposed by the outcome of productive process in the consumer's market. Indeed this is a small fraction of the externalities problems that a system of private law that approaches problems globally should tackle.

This basic change of perspective - from the outcome to the process - is bound to lead to very important insights cutting across a significant section of the substantive rules of the game. This perspective may, more than anything else, cure the presently existing gap between substantive rules, remedies and procedures: a plague that the civilian dogmatic attitude should not infect to the European legal process. Focusing on processes as well as outcomes is likely to allow scholars, policymakers, (and perhaps even the people!) to perceive the importance of the stakes that are on the table.

A progressive European private law, for the time being, does not really exist. In fact, such European private law can only stem from an ideological break with the current phase in which Europe is a servant agency of global capitalism. Such a revolutionary break requires an agenda, capable of spelling out priorities.

Any transformative agenda in European private law should begin with the full disruption of the cages of formalist legal thinking that inhibit to people's appreciation of the full domain of the legal possibility in the process of social transformation and political decisions. ${ }^{182}$ More generally, after formalism, the next enemy of a progressive legal system in Europe is professionalism. Professionalism also should be dismissed as the main agency of legal change. In fact, professionalism is by its very nature an elitist phenomenon, which should be subordinate to a democratic political process.

${ }^{182}$ See Karl E. Klare, Legal Culture \& Transformative Constitutionalism, 14 SAJHR 146 (1998). 
Socially responsible legal change can stem only from the empowerment of the people, thus exploiting the justice motive of the weak and the oppressed. This is why the issue of access to law, which requires a substantial investment of public funds into the judicial process, should be a top priority in our progressive agenda.

Only in a second phase, once the people begin to trust the law again, by fully appreciating its transformative potential, could the task of spelling out the substantive rules of the game be started, perhaps in a first phase along the political compromise of promoting and asserting redistributive and progressive projects within European capitalism. However one should be aware that the social traits of European capitalism were able to develop only in competition with the Socialist alternative. Today, until the threat of such an alternative becomes credible again, it is much more difficult to overcome and transform the many rules, principles and ideologies that are biased in favor of profit over people. But departing from the current ideology remains to be done, so that at least professional disruption of the new European private law industry should happen sooner rather than later.

\section{Restructuring the field: Constitutions and Codes}

In 2005, the French and the Dutch rejected the proposed European Constitution. ${ }^{183}$ In the weeks leading up to the vote, Left and Right political parties strengthened a "No" coalition around two major important claims and obscured other voices in the process, except the one, very popular on the right, of racism and xenophobia. ${ }^{184}$ While racism has been the independent agenda of the right, no such an independent agenda has been produced on the left. The first common claim was that the Constitution would enforce a neo-liberal economic model in

183 See http://europa.eu.int/constitution/referendum_en.htm, "The people of France and the Netherlands rejected the text of the Constitution on 29 May and 1 June respectively. In the light of these results, the European Council, meeting on 16 and 17 June 2005, considered that "we do not feel that the date initially planned for a report on ratification of the Treaty, 1 November 2006, is still tenable, since those countries which have not yet ratified the Treaty will be unable to furnish a clear reply before mid-2007."

184 See Jürgen Habermas, Le non illusoire de la gauche, Nouvel OBSERVATEuR, May 5, 2005 "[... [ La capacité de régulation de l'Etat-nation ne suffit plus depuis longtemps à faire pièce aux conséquences ambivalentes de la mondialisation économique. Ce qui est célébré aujourd'hui comme «modèle social européen» ne peut être défendu que si, dans le cadre même de l'Europe, la politique est capable de revenir à la hauteur des marchés. Ce n'est qu'au niveau européen que l'on pourra récupérer tout ou partie de la capacité de régulation politique de toute façon perdue au niveau de l'Etat-nation. Les membres de 1'UE renforcent aujourd'hui leur coopération dans les domaines qui relèvent de la politique de sécurité - la justice, le droit pénal et l'immigration. Une gauche active et lucide dans sa politique européenne aurait déjà depuis longtemps incité à une harmonisation beaucoup plus poussée, y compris dans les domaines de la politique économique et fiscale." 
the European Union. ${ }^{185}$ The second claim was that national governments should not be part of a technocratic Europe whose decisions take precedence over the decisions of democratically elected national legislatures. ${ }^{186}$ The fundamental paradox that has characterized the constitutional process in Europe might well close the issue of legitimate private law, forcing it into a conundrum. On the one hand, a progressive transformation of private law requires its recognition as a fundamental constitutional choice at the European level; but at the same time many progressive visions, resist major transformations of European private law in fear of capitalistic hegemony. On the other hand, the mainstream conservative forces, those attempting to avoid the encounter between private law and the political process, are the ones more active in pursuing ambitious transformations of the private law system. From this conundrum it is difficult to emerge and progressive legal theory is at risk of suffocation. ${ }^{187}$

In the aftermath of the demise of the European Constitutional treaty, the EU is experiencing a contradictory process which can be looked upon from a global perspective. On the one hand, it is now the institutional structure of a market of some half billion people, with a larger GDP than the United States, experiencing a continuous process of integration from the legal and economic perspective. On the other hand, divisions and rivalry between the most important Member States, as well as the lack of effective political processes and policymaking, as well as of visionary Euro-friendly platforms on the left, have strengthened the notion of a persisting democratic deficit while weakening the institutional imagination of technocrats, jurists and scholars. The outcome of this contradictory process has crated new skepticism and weakened political Europe, which on the one hand is increasingly becoming a periphery of the corporate dominated world, while on the other is increasingly dominated by United States legal scholarship in a variety of legal domains. ${ }^{188}$

In this scenario, it is hard to believe that the making of a socially responsible European private law can be perceived as a top priority, when such fundamental issues such as a common defense, a common foreign policy, a common immigration policy or comparable standards in education and social

\footnotetext{
${ }^{185}$ See Bernard Cassen, ATTAC against the Treaty, New LeFt ReVIEw, May-June 2005 at 27-8 "The collective appropriation of the treaty also had the effect of 'naturalizing' the European question, long considered beyond the scope of national politics. For the first time, the link has been made between neo-liberal policies formulated at EU level and those pursued 'at home."

${ }^{186}$ Id. at 28; on the technocratic Europe see Jan-Werner Müller, After the Double No, The EU's best hope, Boston Review, November-December 2005.

${ }^{187}$ See Duncan Kennedy, supra note 128 (explaining that a third globalization of legal thought is characterized by a new legal consciousness which speaks the language of rights and neoformalism as well as the one of balancing conflicting policy values).

${ }^{188}$ See Mattei Ugo, Why the Wind Changed: Intellectual Leadership in Western Law, 195 AM. J. OF COMP. L. 195 (1994).
} 
protection, are neither solved nor even discussed openly. Nevertheless, the observation that there are more important questions to tackle should not discourage action in the domain of private law. On the contrary, private law in Europe must perform as a constitutional societal space where individuals and groups interact bound by private agreements or publicly enforced constraints thus developing a genuine legal and social identity. ${ }^{189}$

True, as it is well known, the system of private law adjudication as traditionally conceived has neither the sword nor the purse, the former being the province of remedies and enforcement and the latter that of public law. Nevertheless, it is exactly a restructuring of the field of private law that the left should pursue in order to make the law serve the interests of the working class --traditional loser in social processes --- rather than those of the strong corporate interests and of the elite. Within a traditional conception of the field of private law it would be unfair to burden only the shoulders of European private law with the task of radical redistribution of resources, the real issue that should be put on the table today. But things are different when the political spaces of private law are restructured. To put it simply, seen from a genuine leftist agenda, one of the big hurdles in the making of a more socially civilized Europe is that the rich have too many resources (use in part to condition the political process) and the poor too few. Moreover, on average, each North Western European has too much if compared to his South and Eastern fellows; and each European in general has too much if compared to those that are maintained, by violent means, outside of the walls of our shameful fortress. This state of affairs, due to the historical path of capitalistic accumulation, has been very poorly resisted by the working class because the bourgeois hegemony has artificially divided the losers of the political processes, setting the ones against the others in fear of being demoted in their capacity as consumers (an icon of this state of affairs has been the fear of the Polish plumber). From the socialist perspective, that should remain embedded in internationalism, these global inequalities cannot be justified and any legal system can be considered legitimate only as long as it serves a purpose of progressively diminishing them. Unfortunately, internal as well as international distributional questions can only be partly tackled by means of the official (state or EU) production of public law, given the current structure of international relations and the current mainstream agenda in international financial institutions controlling the flux of capitals. Nevertheless, what is not directly possible by official legislation might be incrementally reached by restructuring private law, the backbone of decentralized economic transactions.

\footnotetext{
${ }^{189}$ See Teubner Gunther, Global private regimes: Neo-spontaneous Law and Dual Constitution of Autonomous Sectors in World Society? in Globalization AND PuBlic GovernanCE (Karl-Heinz Ladeur ed., 2003).
} 
Because private law can be considered as a sort of economic constitution there are a few points that should be remarked and fully considered in the scholarly path towards its restructuring. To begin with, private law is one of the fundamental domains in which the problems of externalities arise. It is the very basic legal structure of the market so that issues of environmental harm ${ }^{190}$ and labor standards (just to talk about two of the most socially loaded areas of the law) find into the private law regime the proper venue of discussion. A system of private law that does not approach, in its fundamental philosophy, the political choices that are mandated today by such important areas of externality production, simply fails in its basic role to provide a proper legal regime for a sustainable market. This is an area in which leftist scholarship should not find too many difficulties in setting alliances with approaches more ready to accept capitalism as the fundamental economic constitution of Europe. More difficult it might be to find common platforms in areas such as the division of profit between capital and labor, but even here examples of progressive law to look as models should not be too difficult to find. Job security, limits to the lengths of the workday, maternity and paternity leaves all the way to enterprise congestion and profit sharing have been experienced here and there in the past ${ }^{191}$ and should today be restated, updated and proposed as viable alternatives to uncivilized exploitation. Much of this can be accomplished even by way of interpretation of the existing arsenal of anti-externalities private law remedies. To do so, however, it is a priority that private law should be given a bite by incorporating in its very structure the appropriate institutional apparatus. An apparatus that, from the left could be used to give a real meaning to the idea that private property rights can be tolerated only as far as they can demonstrate a degree of social utility by providing a broad redistribution of income and by sustaining fundamental human needs (think about landlord and tenant law).

Historical experience shows that in order to produce a break with dominant trends capable of re-creating conditions of fairness, there is not only the need for a strong community of legal scholars willing to explore new avenues of inquiry and capable of translating notions such as those of equality and human dignity, always offended by capitalistic exploitation, into rules of private law notions. There is the need for a political will, able to inject into the law a degree

\footnotetext{
${ }^{190}$ See for a first step in this direction, Gerritt Betlem, Environmental liability and the Private Enforcement of Community Law, in Towards a European Civil Code, 677, in Towards a Europe-an Civil Code, 3rd ed, (Martijn. Hesselink et al. eds., Kluwer Law International 2004) arguing for an insertion of this area of the law into the Code.

${ }^{191}$ For example in former Yugolsavia under the leadership of Tito, before Western exploitation and imperialism has turned the Balkans in bloodshed. See G.A. BENACCHIO, LA PROPRIETÀ NELL'IMPRESA AUTOGESTITA JUGOSLAVA (1988).
} 
of political legitimacy and a self-critical philosophy, capable of understanding the current global ideology and departing from it. Finally, there is the need of a recognizable political function in the landscape of the sources of law. We find such visible political inspiration and symbolic power in all the great codifications, from the French, to the German, to the Italian, to the Mexican, to the DDR of 1975 just to offer the most visible examples. Most importantly, a reform of private law, with its inevitable aspect of innovation, break with past, and revolt against a previous order, inherently reflects a desire of progress, of move away from a status quo that is perceived as non-desirable, perhaps also technically but certainly politically and ideologically.

Here are some examples. In 1804 France was trying to move beyond the class privileges of the Ancién Regime. In 1900 Germany was attempting a new start as a mighty unitary empire, away from political divisions and warfare. In 1942 Italy was reacting against the bourgeois and liberal legal order. A similar social revolt though grounded in a socialist rather than in a fascist philosophy, characterized 1950 Mexico. The DDR produced, in 1975 an advanced and innovative Civil Code, in an attempt to overcome bourgeois formalism, professionalism and faked economic equality.

Such a need for political inspiration, to be sure, does not necessarily mean that there is a need or a desire of an autocratic political rule, such as that in place in most of the previous examples. Such inspiration could well come from the bottom up, as a cultural legacy of an intellectual community of critical thinkers worth their salt and not available of being transformed in yet another ideological industry serving the dominant rhetoric. This global community needs to be established. If this is the case, then a political platform capable of inspiring a "not merely technical" system of private law can be inducted from the historical moment that a social community is living, from the tensions and the stakes of such moment, as reflected by constitution making exercises that might and indeed do appear under new clothes in the present post-modern condition. In particular, political inspiration and critical self-reflection can be induced in comparison with other experiences, from a desire of identity of the European community in the post cold war international order.

It would seem natural to seek such guidelines in a project with the symbolic power such as the one represented by a Constitution. ${ }^{192}$ Unfortunately, as already mentioned, the European Constitutional process carried on by the Convention and its presidium has been nothing more than a major failure, the

192 See P.Bourdieu, Space and Symbolic power, IN OTHER WORDS: Essays TOWARDS A REFLEXIVE SOCIOLOGY, 153 (1990) (explaining that "In the symbolic struggle for the production of common sense or, more precisely, for a monopoly over legitimating agents put into action the symbolic capital that they have acquired in previous symbolic struggles which can be juridically guaranteed."). 
product of a political oligarchy, lacking democratic legitimacy and promoting the current neo-liberal order to constitutional status. It misused the label "Constitution" for something that was little more than the charter of an "Old Boys club," seeking in a mythological European past legitimization for the privileges of the present ruling elites while letting out the others. ${ }^{193}$ Unfortunately colonialism, racism and authoritarianism show that the European past (and present) is less than commendable and the present attitude towards anybody born outside of the walls of fortress Europe make the future too dark to be inspirational for someone seeking values for a "real" Constitution.

Despite these serious problems, the European charter of rights would have offered a political mandate for a reform of private law governing the common market. The welfarist nature of European capitalism, despite the refusal of some of the most classic ideas such as the social function of property rights, is reasserted in the charter and is claimed as a strong aspect of European identity. ${ }^{194}$ It might be expanded towards its socialist potentials. Both the political aspiration and the previous path that reform must attempt to interrupt, are therefore a given. The community of progressive legal scholars should interpret, apply and put in practice such political aspirations and self-criticism in the next years of the making of European private law by setting a proper agenda. As enlightened as a scholarly community might be (and we might doubt of the current European private law one, effectively normalized by its transformation into an industry) we should not fall into the romantic Savignian idea (or ideology) that legal scholars are the only interpreters of the "spirit of the people". The people themselves should be empowered to talk about the law in order to make their sense of justice (or of injustice) emerge. This is why we have to turn now to an area, that of access to law, that should become integral part of a restructured progressive notion of European private law. ${ }^{195}$

\section{Restructuring the Field: Whose Access to Justice?}

Access to justice empowers individuals in society. If it grants a bite to the private law system; it may allow at least a minimum check by the people on the current decline of legal civilization. This is why it should be a top priority of a leftist agenda. The smartest legal professional cannot understand the law and see its decline as deeply as someone suffering for its injustice. In "face to faceless

\footnotetext{
${ }^{193}$ See for instance the non-voice of the "new member states" during the constitutional process. The former eastern European countries where in fact given only an observer role without any political power.

${ }^{194}$ European social capitalism is well described as an alternative both to socialism and to neoliberalism by Michael Albert, supra note 151. A somehow more idealized, though highly accessible description is in J.Rifkin, The European Dream (2004).

${ }^{195}$ The classic is here Laura Nader, The Life of the Law (2002).
} 
societies", such as the capitalistic ones, where someone whose rights are violated by a Bank or a Telecom can only complain with an answering machine or with a disempowered human being exploited in some call center, access to law is largely reserved to the haves. Have nots are exluded by a system of courts in which enforcement of rights is progressively more expensive and privatized ${ }^{196}$.

The consequence of this state of affairs is the separation of legal scholars from the real life of the law. With no access to justice the law lacks a soul. It is not a living social creature but it is reduced to a technocratic laboratory of "social engineering". With no people's control of the law, legal civilization is bound to decline. Individuals get disengaged and are transformed in passive spectators of the "spectacle". The civic sense and the social participation into a process of civilization are substituted by a brutish appetite for materialistic consumption. Violated rights, such as those of airline travelers, can be cheaply bought by corporations offering in compensation a few frequent fliers miles.

Currently, western legal civilization is in disarrays, most important because of the attitude towards it of the world economic power. European legal culture should not participate in this downgrading the rule of law into a pale rhetoric, with access to justice only possible through entrepreneurial plaintiff lawyers making out of a selected sample of the disgraces suffered by the many victims of predatory capitalism. With no access to justice the "invisible hand" of legal and economic integration works against the common interest favoring, to the contrary, rent-seeking attitudes of capitalistic predators. Much of today discussions about European private law do not come to term with the grim reality of an almost complete disjunction between the law in the books and what happens in practice.

European private law as a young field of inquiry, whose early contributions date back in the late 1980 s, thus developed in temporal connection with the dismantling of social welfare institutions beginning under European Union policies at the conclusion of the cold War. True, some early work was done by a few pioneers, but European private law, as a field and an industry, is all historically subsequent to the Reagan-Thatcher revolution. This is perhaps no coincidence. The exciting perspective of building a new field could distract legal scholars from the devastation of the very idea of legality and rights produced by that reactionary political platform. Paradoxically, the revolutionary transformation produced by post 1989 neo-liberal triumph was vandalizing legality in countries such as England and the U.S., much admired abroad for their legal systems. Any social platform in European law today should start from a full consciousness of the devastating effect of neo-liberalism on legality and should first attempt a counter-revolution aimed at making good the damage done. In this light, central to

${ }^{196}$ See Laura Nader and Harry Todd, No Access to Law: Alternatives to the U.S. Judicial System (1980). 
a socially concerned platform, much before the need to change a few black letters in our codes should be the issue of access to justice.

The issue of access to justice is particularly instructive from our perspective. In researching the field, ${ }^{197}$ we noticed that a first intensive wave of writing on the field shortly proceeded the so called-Reagan-Thatcher revolution, the moment in which public institutions started being transformed and significantly privatized. Cappelletti's famous collective project ${ }^{198}$, in particular, witnessed a moment of general optimism in the public interest model, an idea of activist, re-distributive, democratizing, public-service minded approach to the public sector in general and to private law in particular. In that intellectual mode of thought, the Welfare State in Western Societies was seen as a point of arrival in civilization, and access to justice was the device through which communities could provide law as a public good, after having provided shelter, healthcare and education to the needy. True, in the same years, Laura Nader's work was already skeptical of the possibility to provide law to the people in faceless industrial societies, and prophetically suspicious towards the rise of the ADR industry, but it was still motivated by a sincere belief in the possibility to bring justice to the people. $^{199}$

Beginning in the early eighties, the global ideological picture changed. Neo-liberal policies, inaugurated by prime minister Thatcher in Great Britain, the crib of the welfare state, and imported on a much weaker institutional background in Reagan's America, were based on the very basic assumption that the Welfare state was simply too expensive. A Western capitalist model, busy to outspend the Soviet block in order to win the cold war, had to save resources by privatizing as much of its welfare services as possible. Public shelters, health, education and justice for the poor were the natural "victims" of such cut-backs. By the end of the eighties, with the "successful" outcome of the cold war, this policy of "privatization" had overcome the boundaries of the Anglo-American world, as well as those of the traditional political right. At the "end of history", redistributional practices, both direct and indirect could not be structurally afforded in the domain of shelter and health, let alone in those, secondary in survival importance, of education and justice.

With no desire to invest money in legal aid and programs of access to courts for the poor, with a quite sustained cultural crusade against the welfare state and its policies, the future of access to justice, in the original sense of granting equal opportunities to litigation for the rich and the poor, seemed quite

\footnotetext{
${ }^{197}$ One of the authors is also the General Reporter for the "Access to Justice" project of the International Academy of Comparative Law conference scheduled for July 2006 in Utrecht.

${ }^{198}$ See M. Cappelletti et al., Access to Justice and the Welfare State (1978)

${ }^{199}$ Laura Nader's intellectual itinerary (and bibliography) can be followed by reading, Laura Nader, The Life of The Law (2002).
} 
grim. Some countries simply stopped worrying about the unsatisfactory state of their systems of access to justice, while others, where the system was more ahead, were undermining its legitimacy by working out even more privatized and justiceremote models of dispute resolution. The birth of the ADR industry, and the development of a professional class of mediators, not necessarily trained in the law, and serving the interests of harmony and non-adversary social control, had transformed the issue of access to courts of law for everybody in that of limiting as much as possible such access, by creating an alternative not based on adversary justice but on harmony and governmentality, ${ }^{200}$ most importantly, quite entirely privatized. These general transformations of western law, involving a variety of aspects of the legal system, including the rehabilitative ideal (itself expensive) in criminal law, and more generally the target of pursuing social justice through law, have been exported worldwide, incorporated in Structural Adjustment Programs and other vehicles of diffusion of "global" legal thinking ${ }^{201}$.

Only in very recent times, some scholars became aware of the fact that in the years of the demise of the Welfare State, access to justice was transformed in a non issue (as witnessed by the disappearance of all the scholarly literature) substituted by a quite opposite and almost certainly "invented" problem, that of "litigation explosion" "202. Accordingly, the solution to the flood of litigation was closing of the doors of adversary justice for everybody, in particular for the weaker market actors and the development of a new "industry" that of ADR governed by the ideology of harmony and social peace. To be sure, the closing of the doors of justice for the non-wealthy constitutes a further empowerment of the strong economic actors. Because there is no legal venue relatively open to the average individual, powerful market actors are free not to confront the social consequences of their actions. With no desire to invest money in law as a public good, what follows is lawlessness and bullying of the strong over the weak. Consequently, after a legitimized process of law reform it is access to justice that claims a role of top priority for any agenda aimed at social justice through the law.

Access to justice is today intimately connected to the idea of consumer's rights, itself central, as we have seen, to the cultural DNA of European private law. It was not by chance that in the previous sections of this Article we have discussed the ideological stakes in unfair consumer's contractual terms. Nevertheless, there is a point that needs to be clarified. A progressive private law

\footnotetext{
${ }^{200}$ In the sense of the famous College de France lectures of M. Foucault.

${ }^{201}$ I discuss this evolution in Ugo Mattei, A Theory of Imperial Law: A Study on U.S. Hegemony and the latin Resistance, 10 IND. J. Global LeGal Stud. 383 (2002), also available online in Global Jurist Frontiers.

${ }^{202}$ See Mark Galanter, News from Nowhere. The Debased Debate on Civil Justice, 71 DENV. U. L. REV. 77 (1993).
} 
agenda can by no means be satisfied even by a fully satisfactory level of consumer's satisfaction guaranteed by some cheap and easily accessible remedial venue. Consumerism has characterized and still characterizes much of the institutional evolution of European private law, and many leftist scholars have perceived it as a progressive platform. Consumerism nevertheless is a foe of a progressive agenda of post -capitalistic transformation of society performing as a trap in which unfortunately some of the best and more generous intellects of leftist legal scholars have fallen. Consumerism only sets a more advanced frontier of global capitalism, making its unsustainable model of development softer, more user-friendly and ultimately more resistant to radical change. One should be aware that the e-transformation of citizens and individuals into consumers is to be sure one of the most dangerous cultural transformations produced by post-modern capitalism. It destroys class consciousness, and disempowers the resisting potential of the proletariat, by transforming even the free time of the working class into non compensated work in which alienated workers, transformed into consumers of useless commodities, relentlessly shop around for better deals, invariably favoring the corporate power ${ }^{203}$. When we point at access to justice as one of the most important areas that should be explored in order to restructure the field of private law, we do not wish to fall into this trap. Corporations are all favorable to cheap venues where consumers can exchange their less than satisfactory merchandises, and are even available to bribe the few ones still having the energy to protest by offering them some material compensation. This allows standards of production to be kept low, with further exploitation of unskilled proletariat in sweat shops and lowers the risk of the rise of actual social responsibility. It is sufficient to see the long lines of consumers in the exchange departments of the major American chains of consumer's goods distribution. These people are made happy by a mere substitution of a defective product with a working one, nobody compensating them for the extra time and expenses arising for the need to return and change a product paid perhaps hundreds of dollars and bought by the retailer in the South of the world for a few cents.

Should the left care for this kind of access to justice? Should obtaining easy ADR venues for slightly more complicated issues than changing a poorly working $\mathrm{CD}$ player be something worth struggling for? The answer is emphatically no. To the contrary, the kind of justice that we need to guarantee is the genuinely redistributive one, in which ill gotten profits are disgorged and in which the people lucky enough to be born within the walls of fortress Europe vindicate, in the public interest, also the rights of their less fortunate fellows on whose suffering and degradation the current pattern of capitalist development is based. What we should care about is the sense of justice of civic individuals

${ }^{203}$ This image of the consumer as someone working without knowing that he is doing so has been introduced for the first time by French sociologist Beaudrillard. 
concerned for their brothers, not that of brutish individualistic consumers. For this kind of access to justice is worth struggling, within a broad conception of private law aimed at offering the institutional framework of a civilized pattern of global exchanges.

5. Diversity and Distribution: Why should we care?

Not only should the left attempt to restructure the field of private law by making it comprehensive of issues of inclusion and social transformation that traditionally are beyond its scope. We should also be aware of some of the most important observations thus far available. The most important lessons in economic sociology in the realm of European contract law came from Gunther Teubner's study on the harmonization process, which began with the Unfair Terms directive transposed in different territories of the EU. ${ }^{204}$ According to Teubner, the harmonization of contract law, rather than unifying has irritated domestic legal regimes, thus creating deeper cleavages among different legal systems. In taking seriously this lesson seriously, one might be tempted to conclude that harmonization or private law rules are per se a self-defeating strategy so that no political agenda can be accomplished by this tool. While Teubner is an atheist with regard to harmonization, he clearly shows that the effects of harmonization in different socio-economic contexts produce more diversity rather than unity. Therefore any welfarist provision, hard code or any private law directive will have different effects as well as a different impact in terms of creating costs or benefits for different groups. It should thus be appreciated in context, with a clear vision of who are the winners and who the losers of the social processes it has produced in order to take side in favor of the latter. In other words, a progressive platform in European private law should operate a distributional analysis and always take side for the weak.

Another important lesson from Teubner's work is that the evaluation of the economic and social impact of harmonized private law rules in the EU is a job not only for economists, but also for lawyers. Such perspective resonates in the works of United States private law scholar Robert Hale who demonstrated in the 1920s how a choice between two different private law rules, including whether a judge or a legislator makes it, entails a new distribution of bargaining power among private individuals. ${ }^{205}$ Thus, in addressing the impact of harmonization on private

\footnotetext{
${ }^{204}$ See Gunther Teubner, Legal Irritants, supra note 97; and more recently, Pierre Legrand, On the Singularity of Law, 47 HARV. INT'L L.J. 517 (2006).

${ }^{205}$ See Robert L. Hale., Bargaining, Duress and Economic Liberty, 43 Colum. L. Rev. 603, 62728 (1943) ("Bargaining power would be different were it not that the law endows some with rights that are more advantageous than those with which it endows others. It is with these unequal rights that men bargain and excerpt pressure on one another. These rights give birth to unequal fruits of bargaining.").
} 
law, progressive lawyers ought to clarify how each particular rule expresses a choice that shapes the bargaining power of the parties directly and indirectly involved in the dispute. ${ }^{206}$

However the diversity triggered by the implementation of European directives is becoming a dramatic one because who will have to bear the highest costs of its dreadful consequences often happen to be consumers over producers, the southern or the new member states over the old core of Member States and the immigrants over the EU citizens. Take for example the Product Liability saga triggered by the directive. In Gonzaléz, ${ }^{207}$ Bilka Lavprisvarehus $A / S^{208}$ and recently in the theatrical repetition of the saga Commission v. France, ${ }^{209}$ the ECJ proved its authority, by finally imposing though a penalty its interpretation of the directive after more than twenty years of French resistance. ${ }^{210}$ The ECJ nonconsumer friendly interpretation of the Product liability directive, often following the Commission view on the matter, has dramatically changed domestic tort rules and their distributional impact not just in France, but also in Spain and Denmark, directly involved in the issue, but throughout Europe. These ECJ cases demonstrate that the regulation of defective products aims to respond to severe personal injuries and health risks for consumers. Thus, in evaluating injuries, risks and allocation of costs through tort law, judges ought to acknowledge the variety of domestic private law regimes -including not only tort but also contract and property rules - as well as the highly diverse national health care systems and pharmaceutical regulations. $^{211}$

In adopting a distributive analysis to inform their decision, progressive jurists should make two preliminary considerations. First, all the above legal factors are crucial because they constitute the background rules, which are closely interrelated to domestic tort law regimes. These background rules shape the bargaining power of the parties involved in the dispute and they have an impact in determining winners and losers in the choice between alternative liability rules.

\footnotetext{
${ }^{206}$ See Duncan Kennedy, The Political Stakes in the "Merely Technical" Issues of Contract law, 1 Eur. Rev. Private L. 7 (2001).

${ }^{207}$ Case C-183/00 Gonzalez Sanchez, 2002 E.C.R. I-3901 25 decided by the ECJ at the same time as Case C-52/00, Comm'n v. France, 2002 E.C.R. I-3827 - 16, Case C-152/00 Comm'n v. Greece 2002 E.C.R. I-3879, 12.

${ }^{208}$ See, Case C- 402/03, Skov Agg versus Bilka Lavprivarehus A/S and Bilka Lavprisvarehus A/S, 2006.

${ }^{209}$ See Case C-177/04, Comm'n v France, 2006, Judgment of the Court (Grand Chamber) of 14 March 2006.

210 See Daniela Caruso, supra note 149.

211 Sapir André, Globalisation and the Reforms of European Social Models (2005) www.bruegel.org . Marie-Eve Arbour, Compensation for Damages Caused by Defective Drugs: European Private Law between Safety Requirements and Free Market Values, 10 EUR. L.J. 87 (2004).
} 
Second, because of the great variety of background rules in the EU -due to the multiplicity of welfare systems as well as private law regimes - the decision to change a liability rule in name of European uniformity, will also increase the unequal redistribution of resources among Member States, thus creating greater diversity and deeper social cleavages rather than better harmonization in the internal market. ${ }^{212}$

For instance, changing a liability rule in Spain or in Greece, where there is a universal or national healthcare system, is radically different than changing a liability rule in continental or Anglo-Saxon Member States in which consumers buy private health insurances at times subsidized by the State. By restricting the protection afforded to consumers by domestic tort rules, European judges have increased inequalities among fellow Europeans. In fact, injured parties situated in Mediterranean countries will find it more difficult to recover than those situated in continental or Anglo-Saxon countries. The latter group of consumers could sue for health related injuries an insurer under contract law rather than tort law. Thus, when the ECJ imposes uniformity on a market that is still divided by social and cultural barriers, which are not necessarily undesirable from a distributive standpoint, it also creates new inequalities among European individuals.

By adopting a distributive analysis, when jurists chose between two alternative private law they have to openly acknowledge and offer to political discussion the costs and the benefits of their decisions for the parties directly and non-directly involved in the dispute. In realizing the effects they are producing, they might suggest softening the need of uniformity or maximal harmonization in European private law. If they decide to continue in their striving for uniformity, rather than justifying their choices through a textualist interpretations or arguments which entail separation of powers and supremacy of Community law, they should openly acknowledge the winners and the losers of the decision to unify a given area. In our case, Spanish medical businesses and Danish distributors clearly won at the expense of national consumers.

To be sure, in acknowledging the costs and benefits stemming from a liability rule, a distributive analysis requires an inquiry into the facts and a thick knowledge of the legal and socio-economic regimes in which the dispute takes place. True, substantive information is available in scholarly works and studies conducted by the European Commission on the varieties of welfare regimes and different product liability systems within the Member States. ${ }^{213}$ If we do not trust such information that might be biased or distorted by the "industry" then we should pay greater attention and debate more openly the role of courts for carrying

${ }^{212}$ This point was first made by Gunter Teubner, Legal Irritants, supra note 97.

${ }^{213}$ See Report From the Commission on the Application of the Directive 85/374 on Liability for Defective Products, COM (2000) 893 final; PaUlette Kurzer. Markets and Morality Regulation. Cultural Change in the European Union (2001). 
out a distributive analysis and openly-acknowledging their political choices in their decision impacting the local context.

\section{Conclusion}

In this article we have surveyed the current debates creating sparks in European private law scholarship and deep dissents among European lawyers. We have explained why the notion of a social private law holds no clarifying meaning and thus remains ambiguous and open to controversies. We have also claimed that a notion of Social Europe is a controversial one, due to the pluralities of welfare regimes as well as the alternative hegemonic project that Europe represents today for global markets.

Our claim is that today in Europe as in the past "the Social" in private law does not necessarily fulfill the needs of a progressive, let alone a socialist agenda. Instead, in coalescing under the rubric that the "Social" scholars have compromised over important issues that should be reconsidered because giving a human face to capitalist exploitation cannot be seen as a progressive agenda.

We have also highlighted some of the main problems and offered methodological alternatives as well as policy proposal for what we called a transformative agenda for a European private law. Our claim is that any project for European private law should go beyond coalitions around social justice. Instead, it should restructure the field of private law by creating strategic alliances on specific targets (access to justice, distributive outcomes, empowerment of labor) linking scholarly, political and judicial forces in the construction of a progressive agenda capable to serve the interests of the multitudes and of human civilization. 